Maurer School of Law: Indiana University

Digital Repository@Maurer Law

Indiana Law Journal

Volume 88 | Issue 3

Article 3

Summer 2013

\title{
An Empirical Study of Certain Settlement-Related Motions for Vacatur in Patent Cases
}

Jeremy Bock

University of Memphis Cecil C. Humphreys School of Law, jwbock@memphis.edu

Follow this and additional works at: https://www.repository.law.indiana.edu/ilj

Part of the Intellectual Property Law Commons

\section{Recommended Citation}

Bock, Jeremy (2013) "An Empirical Study of Certain Settlement-Related Motions for Vacatur in Patent Cases," Indiana Law Journal: Vol. 88 : Iss. 3 , Article 3.

Available at: https://www.repository.law.indiana.edu/ilj/vol88/iss3/3

This Article is brought to you for free and open access by the Law School Journals at Digital Repository @ Maurer Law. It has been accepted for inclusion in Indiana Law Journal by an authorized editor of Digital Repository @ Maurer Law. For more information, please contact rvaughan@indiana.edu.

\section{$\Psi$}

JEROME HALL LAW LIBRARY

INDIANA UNIVERSITY

Maurer School of Law
Bloomington 


\title{
An Empirical Study of Certain Settlement-Related Motions for Vacatur in Patent Cases
}

\author{
JEREMY W. BOCK ${ }^{*}$
}

When parties jointly move to vacate otherwise proper rulings as part of a settlement agreement, district courts often oblige. While the general practice of vacating rulings to facilitate settlement has been criticized in the academic literature as depriving the public of the benefit of judicial precedents, there are hardly any empirical studies on the prevalence of this practice and its effects, particularly at the district court level where the efficiencies arising from settlement-and the resulting pressure on the court to grant vacatur-are much greater compared to the appellate level. This Article endeavors to add an empirical study to the literature on settlement-related vacatur, focusing on district courts in the specific context of patent litigation. In patent cases, the impact of vacating rulings on the public interest is most acute where the affected ruling pertains to the scope, validity, or enforceability of a patent because the cost of relitigating those issues-without the economy of collateral estoppel-may dissuade potential challenges to suspect patents or unmeritorious infringement claims.

The empirical study analyzes a dataset of 79 patent cases in which settlementrelated motions for vacatur were filed over a five-year period (January 2006 to January 2011) that targeted certain rulings adverse to patentees. In those 79 cases, motions for vacatur were granted in 62 cases (78.5\%), denied in 15 cases (19\%), and withdrawn by the parties in 2 cases (2.5\%). The data reveal that district courts appear to prioritize near-term docket management concerns when granting vacatur-even when it would undermine judicial economy and the public interest. Indeed, district courts routinely granted vacatur without providing a reasoned explanation, without regard to the litigation history of the patent or the litigiousness of the patentee, and with a degree of alacrity that would effectively prevent interested third parties from filing timely motions to intervene to oppose vacatur. Overall, the data suggest that granting settlement-related vacatur is a false economy: it leaves the judiciary vulnerable to manipulation, and burdens the public with the anticompetitive effects of weak patents.

$\dagger$ Copyright (C) 2013 Jeremy W. Bock.

* Research Fellow and Senior Visiting Scholar, Berkeley Center for Law \& Technology, University of California, Berkeley, School of Law. The author thanks Jonas Anderson, Robert Barr, T.J. Chiang, Colleen Chien, Ben Depoorter, John Golden, Eric Goldman, Parisa Jorjani, Jeffrey Lefstin, Mark Lemley, Peter Menell, Vivek Nadkarni, David Schwartz, and Darryl Towell for helpful comments. The author also thanks Dr. Su Li for statistical expertise. An earlier draft of this Article was presented at the 2012 Work-inProgress Workshop at U.C. Hastings College of the Law. The compilation, coding, and statistical analysis of all data and results presented in this Article were performed personally by the author based on publicly-available information, and any related inferences, commentary, and recommendations reflect solely his personal views. For statistical analysis, the author used Stata/IC 12.1, a software package available from StataCorp LP (http://www.stata.com). 


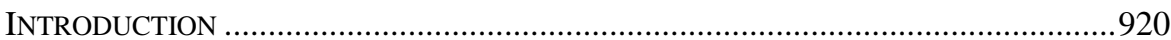

I. CURRENT LEGAL FRAMEWORK ..................................................................9925

II. DESIGN OF EMPIRICAL STUDY AND SUMMARY OF RESULTS.............................993

III. COMPILATION OF THE DATASET ................................................................. 934

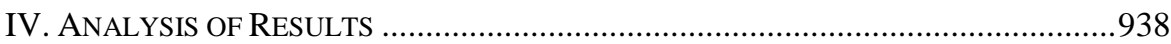

A. PROFILE OF RULINGS TARGETED FOR VACATUR .....................................938

B. MANNER OF DiSPOSITION OF VACATUR MOTION....................................944

C. VACATUR AND CASE DURATION...........................................................946

D. VACATUR AS A CONDITION OF SETTLEMENT ......................................951

E. PATENT Characteristics, VACATUR, AND RELITIGATION ...................954

F. AVAILABILITY OF INTERVENTION......................................................967

V. IMPLICATIONS AND RECOMMENDATIONS .......................................................992

A. PERSUASIVE PRECEDENT IS Not ENOUGH ............................................972

B. APPELLATE CONSIDERATIONS ............................................................ 974

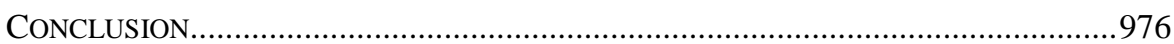

APPENDIX A: IPLC SEARCH PARAMETERS ................................................... 978

APPENDIX B: WESTLAW SEARCH PARAMETERS .................................................. 978

APPENDIX C: DOCKET NAVIGATOR SEARCH PARAMETERS ..................................979

\section{INTRODUCTION}

The practice of courts vacating ${ }^{1}$ otherwise proper rulings for no reason other than that the parties have requested it in connection with a settlement raises questions about the public nature of adjudication and the risk of strategic behavior by litigants. ${ }^{2}$ However, to the litigants who request such relief, and the courts that grant it, its virtue lies in its apparent efficiency in facilitating settlement to conserve both private and public resources. Are they right? Or, could the grant of vacatur be a false economy? This is a question over which opinions differ, even among eminent jurists. ${ }^{3}$ Yet, empirical studies of the prevalence and effects of settlement-

1. Vacatur is " $[\mathrm{t}]$ he act of annulling or setting aside." BLACK's LAW DiCTIONARY 1688 (9th ed. 2009). The verb form is "vacate," which is defined as "[t]o nullify or cancel; make void; invalidate <the court vacated the judgment>." Id.

2. See, e.g., Jill E. Fisch, Rewriting History: The Propriety of Eradicating Prior Decisional Law Through Settlement and Vacatur, 76 CORNELl L. REV. 589, 593 (1991) ("[T]he effect of vacatur on the litigation process extends beyond judicial waste; it perverts the judicial decision into a negotiable commodity, engendering distortion of, and disrespect for, the role of the courts."); see also Rex R. Perschbacher \& Debra Lyn Bassett, The End of Law, 84 B.U. L. REV. 1, 54-55 (2004) ("[C]ourts have, in essence, 'rediscovered' the vacatur procedure ... and have created something very different and potentially dangerous to law."); Daniel Purcell, Comment, The Public Right to Precedent: A Theory and Rejection of Vacatur, 85 CALIF. L. REv. 867, 916 (1997) (“[A] litigant has no right to be free of a nondefective adverse judgment.").

3. See Sarah Rudolph Cole, Managerial Litigants? The Overlooked Problem of Party Autonomy in Dispute Resolution, 51 Hastings L.J. 1199, 1227-28 (2000) (“According to Judge Winter of the Second Circuit, a decision not to vacate a judgment wastes both the litigants and the court's resources by requiring the continuation of litigation that could have 
related vacatur are scarce ${ }^{4}$ and focus primarily on appellate courts, ${ }^{5}$ which may not account for the specific characteristics of district courts, ${ }^{6}$ where the potential savings in judicial economy from settlement are far greater. ${ }^{7}$

This Article analyzes the results of an empirical study on settlement-related vacatur at the district court level, focusing specifically on patent cases. Patent cases are well suited for detailed empirical investigations because of the availability of specialized databases-such as the Stanford IP Litigation Clearinghouse (IPLC) ${ }^{8}$ and Docket Navigator ${ }^{9}$ - that allow the systematic searching and review of district court patent case dockets collected from PACER. ${ }^{10}$

In addition, the potential for repetitive litigation makes patent cases a propitious vehicle for studying the conditions under which settlement-related vacatur is requested and granted. A patentee who files suit risks having the asserted patent narrowed in scope, invalidated, or held unenforceable. When confronted with an adverse ruling that could impair future assertions, licensing, or the overall valuation of the asserted patent, most patentees will eventually settle. ${ }^{11}$ To escape the consequences of an adverse ruling without further litigation, some patentees will

been settled. . . . By contrast, Judge Easterbrook, analyzing the same problem, came to the opposite conclusion.").

4. Id. at 1229 ("[I]t is difficult to draw a firm conclusion about the efficacy of the vacatur practice in the absence of empirical evidence.").

5. See, e.g., Stephen R. Barnett, Making Decisions Disappear: Depublication and Stipulated Reversal in the California Supreme Court, 26 Loy. L.A. L. REV. 1033, 1073 n.221 (1993) (empirical study of stipulated reversals in California appellate courts concluding that stipulated reversal is not an important factor in promoting settlement).

6. See, e.g., Pauline T. Kim, Margo Schlanger, Christina L. Boyd \& Andrew D. Martin, How Should We Study District Judge Decision-Making?, 29 WASH. U. J.L. \& PoL'Y 83, 87 (2009) ("[I]n the relatively scant empirical literature on district courts, little attention has been paid to how their institutional features shape judges' decision-making. Empirical studies of district courts have tended unreflectively to borrow models developed to study the appellate courts . . . .); Judith Resnik, Managerial Judges, 96 HARV. L. REV. 374, 418 (1982) [hereinafter Resnik, Managerial Judges] ("[W]hat works for the courts of appeals cannot simply be transplanted into trial courts.").

7. See, e.g., U.S. Bancorp Mortg. Co. v. Bonner Mall P'ship, 513 U.S. 18, 28 (1994) ("[T]he judicial economies achieved by settlement at the district-court level are ordinarily much more extensive than those achieved by settlement on appeal.").

8. Stanford IP Litigation Clearinghouse, STAN. L. SCH., http://www.law.stanford.edu/ program/centers/iplc. The IPLC is presently operated by a private company, Lex Machina, Inc. in Palo Alto, California. (For more information on the company, see LEX MACHINA, https://lexmachina.com.) The dataset for the empirical study reported in this Article was compiled primarily through the IPLC. See infra Part III.

9. Docket Navigator is provided by Hopkins Bruce Publishers Corp., in Abilene, Texas. See DocKet NAVIGATOR, https://docketnavigator.com.

10. PACER, which is an acronym for Public Access to Court Electronic Records, is an electronic service provided by the federal judiciary that allows users to obtain case information from federal appellate, district, and bankruptcy courts. PACER, http://www.pacer.gov.

11. See Jay P. Kesan \& Gwendolyn G. Ball, How Are Patent Cases Resolved? An Empirical Examination of the Adjudication and Settlement of Patent Disputes, 84 WASH. U. L. REv. 237, 259 (2006) (empirical study of patent cases filed in 1995, 1997, and 2000, finding that "approximately $80 \%$ of patent cases settle"). 
attempt to secure its nullification in the course of reaching a settlement. Because a vacated ruling has no preclusive or precedential force, ${ }^{12}$ this option is attractive to patentees who want to strip any potential collateral estoppel ${ }^{13}$ effect from an inconvenient ruling. ${ }^{14}$ To make vacatur more palatable to the district court, which likely invested considerable resources to produce the ruling targeted for vacatur, a patentee typically requests vacatur in an unopposed or joint motion with the accused infringer, who, in accordance with the settlement agreement, acquiesces in its filing. ${ }^{15}$ In some instances, a patentee may expressly condition the settlement on the grant of vacatur, such that a denial will void the settlement. Consistent with the judiciary's strong preference for settlement, ${ }^{16}$ district courts granted vacatur in a clear majority of cases in the dataset $(78.5 \% \text {; } 62 \text { out of } 79 \text { cases })^{17}$ compiled for this Article. This is not surprising given that district judges are under pressure to manage their dockets efficiently and clear any backlogs, ${ }^{18}$ and so settlement is the

12. Vacatur "clears the path for future relitigation of the issues between the parties and eliminates a judgment." United States v. Munsingwear, Inc., 340 U.S. 36, 40 (1950); see also Rumsfeld v. Freedom NY, Inc., 329 F.3d 1320, 1332 (Fed. Cir. 2003) (“[A] vacated judgment has no preclusive force either as a matter of collateral or direct estoppel or as a matter of the law of the case." (citation omitted) (internal quotation marks omitted)).

13. Collateral estoppel, also known as issue preclusion, may bar relitigation of an issue if: (1) the issue is identical to one decided in a prior action; (2) the issue was actually litigated in the prior action; (3) the resolution of the issue was essential to a final judgment in the prior action; and (4) the party defending against issue preclusion had a full and fair opportunity to litigate the issue in the prior action. Shell Petroleum, Inc. v. United States, 319 F.3d 1334, 1338 (Fed. Cir. 2003).

14. Collateral estoppel may be used to establish: (1) invalidity, see, e.g., BlonderTongue Labs., Inc. v. Univ. of Ill. Found., 402 U.S. 313 (1971) (holding that any subsequent defendant may reap benefit of prior invalidity decision under principles of collateral estoppel); (2) unenforceability, see, e.g., Pharmacia \& Upjohn Co. v. Mylan Pharm., Inc., 170 F.3d 1373, 1379 (Fed. Cir. 1999) ("An unrelated accused infringer may likewise take advantage of an unenforceability decision under the collateral estoppel doctrine."); (3) noninfringement, see, e.g., Molinaro v. Fannon/Courier Corp., 745 F.2d 651, 655 (Fed. Cir. 1984) (affirming district court's grant of summary judgment of noninfringement based on collateral estoppel); and (4) claim constructions, see, e.g., TM Patents, L.P. v. IBM Corp., 72 F. Supp. 2d 370, 375-79 (S.D.N.Y. 1999) (according collateral estoppel effect to a claim construction order).

15. Throughout this Article, the term "motion" will refer to motions for vacatur that are jointly filed or unopposed, unless specified otherwise.

16. The judiciary's preference for settlement is succinctly expressed in "the familiar axiom that a bad settlement is almost always better than a good trial." In re Warner Comm'ns Sec. Litig., 618 F. Supp. 735, 740 (S.D.N.Y. 1985); see also Judith Resnik, Mediating Preferences: Litigant Preferences for Process and Judicial Preferences for Settlement, 2002 J. DisP. RESOL. 155, 159 ("[J]udges have put their institutional authority behind settlement as the mode of disposition to be preferred.").

17. See infra Part IV.

18. See, e.g., David A. Hoffman, Alan J. Izenman \& Jeffrey R. Lidicker, Docketology, District Courts, and Doctrine, 85 WASH. U. L. REv. 681, 705-06 (2007) ("[S]cholars have been insufficiently attendant to the shaming sanctions that judges face if they fall too far behind on their docket. In essence, Congress (through the Administrative Office) publishes a list naming judges whose dockets are too full. Such dilatory judges face the gentle ribbing of 
preferred method for case disposal because it clears the docket without the risk of appeal and reversal. ${ }^{19}$

However, the routine nullification of rulings affecting the scope, validity, or enforceability of a patent adversely affects the public interest, ${ }^{20}$ as it facilitates the reassertion of weak patents ${ }^{21}$ and undermines the finality of judgments. ${ }^{22}$ Once the unfavorable rulings associated with a patent have been vacated, the patentee can freely assert that patent against other potential defendants, who are confronted with the choice of relitigating the same issues at considerable expense ${ }^{23}$ or taking a license to a patent that might be invalid, unenforceable, or not infringed. ${ }^{24}$

their fellows at the judicial lunch table and the harsh glare of the media spotlight.").

19. Judge Richard Posner of the Seventh Circuit, who often sits by designation at the trial court level, summarizes this dynamic as follows:

District judges often have heavy dockets; a single judge in an urban district will have several hundred cases pending before him. Most of these will be settled or abandoned without the judge's intervention. But enough will remain that require court action to induce the judge to attend to them lest his backlog become unmanageable. He cannot be cavalier in disposing of these cases, as then his reversal rate would rise to an embarrassing level. So backlog pressure keeps him working hard and reversal threat keeps him working carefullythough an alternative strategy is to push the parties to settle, since settlements reduce backlog without risk of reversal.

Richard A. Posner, How Judges THINK 141 (2008).

20. See, e.g., Blonder-Tongue Labs., Inc. v. Univ. of Ill. Found., 402 U.S. 313, 343 (1971) ("“A patent by its very nature is affected with a public interest. . . The far-reaching social and economic consequences of a patent, therefore, give the public a paramount interest in seeing that patent monopolies spring from backgrounds free from fraud or other inequitable conduct and that such monopolies are kept within their legitimate scope."' (quoting Precision Instrument Mfg. Co. v. Auto. Maint. Mach. Co., 324 U.S. 806, 816 $(1945)))$.

21. See, e.g., Lear, Inc. v. Adkins, 395 U.S. 653, 674 n.19 (1969) (noting "the public's interest in the elimination of specious patents").

22. See, e.g., Cardinal Chem. Co. v. Morton Int'l, Inc., 508 U.S. 83, 100 (1993) (“'[O]ur prior cases have identified a strong public interest in the finality of judgments in patent litigation.").

23. In 2011, the median cost of patent litigation for cases having: (i) less than $\$ 1$ million at risk was $\$ 650,000$; (ii) $\$ 1-\$ 25$ million at risk was $\$ 2.5$ million; and (iii) more than $\$ 25$ million at risk was $\$ 5$ million. Law Practice Mgmt. Comm., Am. Intellectual Prop. Law AsSOC., REPORT OF THE ECONOMIC SURVEY 35 (2011).

24. See, e.g., Blonder-Tongue, 402 U.S. at 338 ("In each successive suit the patentee enjoys the statutory presumption of validity, and so may easily put the alleged infringer to his expensive proof. As a consequence, prospective defendants will often decide that paying royalties under a license or other settlement is preferable to the costly burden of challenging the patent."). Experienced patent jurists at the district court level, such as Leonard Davis of the Eastern District of Texas and T.S. Ellis, III, of the Eastern District of Virginia, have expressed similar concerns about the distortion of patent litigation by its sheer cost. See, e.g., Memorandum Opinion and Order at 5, Raylon LLC v. Complus Data Innovations, No. 6:09cv-00355-LED (E.D. Tex. Mar. 9, 2011), ECF No. 147 (Davis, J.) (“[T]his Court has some concerns about plaintiffs who file cases with extremely weak infringement positions in order to settle for less than the cost of defense .... Such a practice is an abuse of the judicial 
Furthermore, given the complex and highly contentious nature of patent litigation, ${ }^{25}$ considerable judicial resources were likely spent adjudicating the vacated rulings, which may include claim construction orders, summary judgment rulings, and even jury verdicts. ${ }^{26}$ Despite the significant competing interests of the settling parties, the public, and the judiciary implicated by settlement-related motions for vacatur ${ }^{27}$ in patent cases, there is not much guidance in the caselaw on when it may be appropriate for a district court to grant or deny them. ${ }^{28}$

In the absence of clear precedent, empirical research may help bring into relief the various considerations-both public and private-for evaluating whether granting settlement-related vacatur may be appropriate in a particular case and to inform further doctrinal development. ${ }^{29}$ Timing-wise, an empirical study would be useful in light of certain trends and recent developments in the patent field that may prompt patentees to file settlement-related vacatur motions in more cases. First, the patent monetization trend is accelerating, whereby practicing companies, with their patent stockpiles, are increasingly adopting the tactics of-and, in some cases, selling their patents to and even teaming up with-patent assertion entities (PAEs) $^{30}$ (colloquially known as "patent trolls") to generate revenue through

system and threatens the integrity of and respect for the courts."); T.S. Ellis, III, Distortion of Patent Economics by Litigation Costs, in 5 CASRIP Publication SERIES: STREAMLINING INT'L INTELLECTUAL PROPERTY 22, 23 (1999), available at http://www.law.washington.edu/ casrip/symposium/Number5/pub5atcl3.pdf ("[B]urgeoning litigation costs have distorted patent markets by significantly discouraging potential patent challenges, hence distorting competition to a degree beyond that justified by the intrinsic strength or merit of the patent.").

25. See, e.g., Kathleen M. O’Malley, Patti Saris \& Ronald H. Whyte, A Panel Discussion: Claim Construction from the Perspective of the District Judge, 54 CASE W. RES. L. REV. 671, 682 (2004) ("Patent litigation is like the neurosurgery of litigation: it is hard scientifically and it is hard legally. Trial court judges kill themselves on a trial . . . Every single issue is raised; every one is preserved." (statement of Judge Patti Saris of the District of Massachusetts)).

26. See infra Part IV.A.1.

27. See generally 11 Charles Alan Wright, Arthur R. Miller \& Mary Kay Kane, Federal Practice and Procedure: Civil $§ 2863$ (2d ed. 1995) (observing that when parties request vacatur in connection with settlement, " $[\mathrm{t}]$ he question involves a balancing of the desire to encourage voluntary settlements and reduce appeals with the public interest in preserving the judgment to enhance judicial economy by allowing it to be used for issue preclusion purposes and in avoiding the possibility that repeat litigants effectively may control the development of the law by erasing unfavorable judgments").

28. See infra Part I.

29. Cf. Richard A. Posner, The Summary Jury Trial and Other Methods of Alternative Dispute Resolution: Some Cautionary Observations, 53 U. CHI. L. REv. 366, 393 (1986) ("[T]he federal courts have been an arena of massive experimentation in judicial administration. . . . Very few of these experiments have been conceived or evaluated in a scientific spirit and this may help explain why the federal courts remain in a state of crisis. Maybe a dose of social science is the thing, or one of the things, that the system needs.").

30. Patent assertion entities (PAEs) are firms whose business model focuses on purchasing and asserting patents. Colleen V. Chien, From Arms Race to Marketplace: The Complex Patent Ecosystem and Its Implications for the Patent System, 62 Hastings L.J. 297, 300 (2010) [hereinafter Chien, Arms Race] (defining PAEs); see also Fed. Trade Comm'N, The Evolving IP Marketplace: Aligning Patent Notice And ReMEdies with Competition 8 n.5 (2011), 
aggressive licensing campaigns backed by enforcement litigation. ${ }^{31}$ As a result, increasing numbers of patentees may seek vacatur of an adverse ruling that affects a patent with a prior history of successful licensing in order to maintain the flow of royalty payments. Second, the recently-enacted Leahy-Smith America Invents Act of 2011 restricts the joinder of defendants to those instances where there exist questions of fact common to all the defendants, and the alleged infringement arises out of "the same transaction, occurrence, or series of transactions or occurrences." 32 Accordingly, a patentee who intends to assert the same patent against multiple defendants will have a strong incentive to seek vacatur of any adverse rulings that may have preclusive effects in other suits.

Against this backdrop, the empirical study presented in this Article explores the current practice relating to settlement-related vacatur in patent cases to determine how and to what extent the practice should be curtailed. To provide the necessary context for the presentation of the results and their implications, Part I provides an overview of the current legal framework under which settlement-related motions for vacatur are brought. Part II describes the design of the empirical study and provides a summary of the results. Part III explains the compilation of the dataset. Part IV analyzes the results from the dataset relating to the content, filing, and disposition of vacatur motions, as well as certain second-order effects on the public interest and judicial economy. Part V discusses further implications and provides recommendations for future doctrinal development. A brief conclusion summarizes the salient points.

\section{CURRENT LEGAL FRAMEWORK}

At the district court level, motions to vacate an otherwise proper ruling in order to facilitate settlement are typically brought under Fed. R. Civ. P. 60(b)(6) or 54(b), depending on the procedural posture of the case at the time of the motion. If the motion is filed after the entry of final judgment, ${ }^{33}$ a district court may consider it under Rule 60(b)(6), which empowers the court to grant relief from a final judgment for "any other reason that justifies relief" ${ }^{34}$ if "extraordinary

available at $\mathrm{http}: / / \mathrm{www} . \mathrm{ftc}$.gov/os/2011/03/110307patentreport.pdf (using similar definition of PAEs).

31. Chien, Arms Race, supra note 30, at 342 ("A number of companies . . . have found it profitable to enforce, through licensing, their once defensive portfolios. Others, like General Electric, ... sue companies in technology areas in which they do not practice. Practicing company patents, when sold on the market, can also end up being asserted by patentassertion entities.").

32. Leahy-Smith America Invents Act, Pub. L. No. 112-29, § 19, 125 Stat. 284, 333 (2011) (codified at 35 U.S.C. § 299).

33. "A 'final decision' generally is one which ends the litigation on the merits and leaves nothing for the court to do but execute the judgment." Catlin v. United States, 324 U.S. 229, 233 (1945) (citation omitted).

34. Fed. R. Civ. P. 60(b)(6). The grounds for relief from a final judgment under Fed. R. Civ. P. 60(b) are:

(1) mistake, inadvertence, surprise, or excusable neglect;

(2) newly discovered evidence that, with reasonable diligence, could not have been discovered in time to move for a new trial under [FED. R. CIV. P.] 59(b); 
circumstances" exist. ${ }^{35}$ If the motion is filed prior to the entry of final judgment, a district court may consider it under Rule 54(b), ${ }^{36}$ which vests the court with inherent authority to modify or reconsider non-final or "interlocutory" orders. ${ }^{37}$ Although the invocation of collateral estoppel generally requires a final judgment, ${ }^{38}$ interlocutory orders may also be accorded collateral estoppel effect under certain circumstances, ${ }^{39}$ such that parties will often seek vacatur of non-final rulings out of

(3) fraud (whether previously called intrinsic or extrinsic), misrepresentation, or misconduct by an opposing party;

(4) the judgment is void;

(5) the judgment has been satisfied, released, or discharged; it is based on an earlier judgment that has been reversed or vacated; or applying it prospectively is no longer equitable; or

(6) any other reason that justifies relief.

FED. R. CIV. P. 60(b). Of the six enumerated reasons, only the Rule 60(b)(6) "catch-all" could potentially accommodate a motion to vacate an otherwise proper ruling after the entry of final judgment. The other enumerated reasons in Rule 60(b)(1)-(5) relate to situations where the judgment is in some way defective or no longer appropriate, and thus warrant vacatur for reasons other than simply to facilitate settlement.

35. See, e.g., Liljeberg v. Health Servs. Acquisition Corp., 486 U.S. 847, 863-64 (1988) (observing that Rule 60(b)(6) "does not particularize the factors that justify relief, but we have previously noted that it provides courts with authority adequate to enable them to vacate judgments whenever such action is appropriate to accomplish justice, while also cautioning that it should only be applied in "extraordinary circumstances"' (internal citations omitted) (quotation marks omitted)); see also Valero Terrestrial Corp. v. Paige, 211 F.3d 112,118 n.2 (4th Cir. 2000) (observing that "the difference between Rule 60(b)(6) and Rules $60(b)(1)-(5)$ is that 'extraordinary circumstances' are required to bring the [Rule 60(b)(6)] motion within the 'other reason' language of that Rule" (alteration in original) (internal quotations omitted) (citing Liljeberg, 486 U.S. at 863 n.11)); see also 12 JAMES WM. MOORE, Moore's Federal Practice: Civil $§ 60.48$ (Daniel R. Coquillette, Gregory P. Joseph, Sol Schreiber, Georgene M. Vairo \& Chilton Davis Varner eds., 3d ed. 2012); 11 WRIGHT ET AL., supra note 27 at $\S 2864$.

36. Fed. R. Civ. P. 54(b) provides, in pertinent part:

[A]ny order or other decision, however designated, that adjudicates fewer than all the claims or the rights and liabilities of fewer than all the parties does not end the action as to any of the claims or parties and may be revised at any time before the entry of a judgment adjudicating all the claims and all the parties' rights and liabilities.

FED. R. Civ. P. 54(b).

37. An "interlocutory order" is "[a]n order that relates to some intermediate matter in the case; any order other than a final order." BLACK's LAW DiCTIONARY 1207 (9th ed. 2009).

38. See supra note 13.

39. See, e.g., Dana v. E.S. Originals, Inc., 342 F.3d 1320, 1323-25 (Fed. Cir. 2003) (applying Eleventh Circuit law in holding that partial summary judgment orders satisfied legal prerequisites for applying collateral estoppel). Whether a ruling is entitled to collateral estoppel effect is a procedural issue, such that a district court would apply the law of its regional circuit-rather than Federal Circuit law-in analyzing whether the doctrine is applicable in a given case. See Bayer AG v. Biovail Corp., 279 F.3d 1340, 1345 (Fed. Cir. 2002) ("Because the application of collateral estoppel is not a matter within the exclusive jurisdiction of this court, this court applies the law of the circuit in which the district court sits ...." (internal citation omitted)). Some circuits have a stricter view of the finality requirement for collateral estoppel than others. Compare Golman v. Tesoro Drilling Corp., 
an abundance of caution. ${ }^{40}$ Under either Rule 60(b)(6) or Rule 54(b), the decision to vacate is committed to the discretion of the district court ${ }^{41}$ and is evaluated under the law of the regional circuit unless the motion implicates patent law, at which point Federal Circuit law applies. ${ }^{42}$ However, as explained below, the Federal Circuit has thus far provided scant—and possibly conflicting_-guidance to the district courts on when settlement-related vacatur may be appropriate. ${ }^{43}$

In general, the leading case on the subject is the Supreme Court's 1994 opinion in U.S. Bancorp Mortgage Co. v. Bonner Mall Partnership, ${ }^{44}$ a bankruptcy case that settled after the Supreme Court granted certiorari. ${ }^{45}$ In Bancorp, the Supreme Court denied the petitioner's motion to vacate the judgment under review, holding that " $[w]$ here mootness results from settlement ... the losing party has voluntarily forfeited his legal remedy by the ordinary processes of appeal or certiorari, thereby surrendering his claim to the equitable remedy of vacatur. ${ }^{, 46}$ In characterizing vacatur as an "extraordinary remedy" to which "equitable entitlement" must be shown, ${ }^{47}$ the Court stressed that "mootness by reason of settlement does not justify vacatur" in the absence of "exceptional circumstances," where "exceptional

700 F.2d 249, 253 (5th Cir. 1983) ("An order granting partial summary judgment is interlocutory; it has no res judicata or collateral estoppel effect."), with Lummus Co. v. Commonwealth Oil Ref. Co., 297 F.2d 80, 89 (2d Cir. 1961) (Friendly, J.) (“"Finality' . . . may mean little more than that the litigation of a particular issue has reached such a stage that a court sees no really good reason for permitting it to be litigated again."). For this reason, Federal Circuit Judge Timothy Dyk has observed that the goal of uniformity in patent law may be better served by having the Federal Circuit apply its own rules on collateral estoppel. See, e.g., Vardon Golf Co. v. Karsten Mfg. Corp., 294 F.3d 1330, 1336 (Fed. Cir. 2002) (Dyk, J., concurring) ("There is simply no reason why an earlier patent judgment should have one consequence in the Third Circuit and another in the Seventh Circuit, for example. Such an approach encourages the very forum shopping that our regional circuit law approach was designed to prevent.").

40. See infra Parts IV.A.1-2.

41. See, e.g., 12 MoORE, supra note 35, at $\$ 56.124[1]$ ("Courts have inherent power to reconsider interlocutory orders [under Rule 54(b)], including grants of partial summary judgment and denials of summary judgment."); 11 WRIGHT ET AL., supra note 27, at $§ 2857$ ("As is recognized in many cases, a motion for relief from a judgment under Rule 60(b) is addressed to the discretion of the court ....").

42. Compare Louisville Bedding Co. v. Pillowtex Corp., 455 F.3d 1377, 1379 (Fed. Cir. 2006) ("A district court's denial of a motion under [Rule] 60(b)(6) is not a procedural issue unique to patent law, and thus we will apply the law of the regional circuit court . . . Moreover, the underlying reasons for Louisville's Rule 60(b)(6) motion . . . do not uniquely implicate patent law." (citation omitted)), with Fiskars, Inc. v. Hunt Mfg. Co., 279 F.3d 1378, 1381 (Fed. Cir. 2002) ("[W]hen a district court's Rule 60(b) ruling turns on substantive matters that pertain to patent law, we review the ruling under Federal Circuit law because 'we perceive a clear need for uniformity and certainty in the way the district courts treat [the] issue."” (second alteration in original) (quoting Broyhill Furniture Indus., Inc. v. Craftmaster Furniture Corp., 12 F.3d 1080, 1083 (Fed. Cir. 1993))).

43. See infra notes 58-86 and accompanying text.

44. 513 U.S. 18 (1994).

45. Id. at 20 .

46. Id. at 25 .

47. Id. at 26 . 
circumstances do not include the mere fact that the settlement agreement provides for vacatur. $" 48$

Because Bancorp was decided in the context of vacatur by federal appellate courts, which is governed by 28 U.S.C. $\S 2106,{ }^{49}$ its holding is not considered binding precedent for district courts. ${ }^{50}$ Indeed, the Court sidestepped the issue of vacatur at the district court level by concluding the Bancorp opinion with a suggestion to the appellate courts to essentially punt the issue:

[E]ven in the absence of, or before considering the existence of, extraordinary circumstances, a court of appeals presented with a request for vacatur of a district-court judgment may remand the case with instructions that the district court consider the request, which it may do pursuant to Federal Rule of Civil Procedure 60(b). ${ }^{51}$

Nevertheless, because the holding in Bancorp turns on the equitable nature of vacatur as a form of extraordinary relief-as opposed to any inherent characteristics of the appellate courts ${ }^{52}$-at least one regional circuit court has treated the Bancorp "exceptional circumstances" requirement as being essentially coextensive with the showing of "extraordinary circumstances" required for Rule $60(b)(6),{ }^{53}$ which similarly precludes relief if the movant deliberately chose not to appeal. ${ }^{54}$ However, not all circuits share this view, as some have espoused a less rigorous standard than "extraordinary circumstances" for settlement-related vacatur at the district court level. ${ }^{55}$ Further complicating the situation is the lack of

48. Id. at 29

49. The Supreme Court and the courts of appeal derive their power to vacate judgments from 28 U.S.C. $\$ 2106$, which states:

The Supreme Court or any other court of appellate jurisdiction may affirm, modify, vacate, set aside or reverse any judgment, decree, or order of a court lawfully brought before it for review, and may remand the cause and direct the entry of such appropriate judgment, decree, or order, or require such further proceedings to be had as may be just under the circumstances.

28 U.S.C. $\$ 2106$ (2006).

50. See, e.g., Valero Terrestrial Corp. v. Paige, 211 F.3d 112, 117 (4th Cir. 2000) (observing that "the holding of Bancorp extends only to appellate court vacatur"); see also Dana v. E.S. Originals, Inc. 342 F.3d 1320, 1328 (Fed. Cir. 2003) (Dyk, J., concurring) (" $[\mathrm{B}] \mathrm{y}$ its terms, Bancorp does not apply to district courts but rather only to the Supreme Court and to courts of appeals." (citing Valero, 211 F.3d at 117-20)).

51. Bancorp, 513 U.S. at 29.

52. See Valero, 211 F.3d at 118-19 ("[T]he particular considerations adopted by the Court in Bancorp derived exclusively from the extraordinary and equitable nature of the relief of vacatur, rather than ... from any power or ability unique to the appellate courts.").

53. See id. at 121 ("[T]he Bancorp considerations that are relevant to appellate vacatur for mootness are also relevant to, and likewise largely determinative of, a district court's vacatur decision for mootness under Rule 60(b)(6) . ...”); supra note 35.

54. See Ackermann v. United States, 340 U.S. 193, 200 (1950) (holding that petitioner was not entitled to relief under Rule 60(b)(6) because of his "voluntary, deliberate, free, untrammeled choice ... not to appeal").

55. See, e.g., Marseilles Hydro Power LLC v. Marseilles Land \& Water Co., 481 F.3d 
precedent governing the settlement-related vacatur of interlocutory rulings under Rule 54(b) ${ }^{56}$ even though, as discussed in greater detail in Part IV, a substantial proportion of vacatur motions are filed prior to the entry of final judgment. ${ }^{57}$

Turning now to the Federal Circuit, no post-Bancorp ${ }^{58}$ Federal Circuit decision has squarely analyzed the merits of a district court's decision to grant or deny vacatur in light of various private, public, and judicial considerations. To the extent that post-Bancorp Federal Circuit precedent exists, it either relates to procedural or collateral issues without reaching the merits of the district court's disposition of a vacatur motion, ${ }^{59}$ or focuses on the Federal Circuit's own ability to vacate the judgment of its subordinate tribunals. ${ }^{60}$

The lack of instructive Federal Circuit precedent reflects the rarity of appeals challenging a district court's disposition of a settlement-related motion for vacatur. In order for such an appeal to exist, a third-party objector who was properly granted

1002, 1003 (7th Cir. 2007) ("The Court in Bancorp said that the court of appeals can remand a case even in the absence of [exceptional] circumstances, which would make no sense if the district court could not vacate its judgment in that absence." (internal citation omitted)); Am. Games, Inc. v. Trade Prods., Inc., 142 F.3d 1164, 1169 (9th Cir. 1998) ("According to the post-[Bancorp] Ninth Circuit decisions, the district court below could have vacated its own judgment using [an] equitable balancing test even if [the parties] had mooted their case by settlement.").

56. See, e.g., Lycos, Inc. v. Blockbuster, Inc., No. 07-11469-MLW, 2010 U.S. Dist. LEXIS 136252, at *7 (D. Mass. Dec. 23, 2010) ("Although the court has the power to modify the orders at issue, there is little authority describing when, if ever, the court should exercise this power to grant vacatur of a non-final order in connection with settlement.").

57. See infra Parts IV.A.1-2.

58. Pre-Bancorp cases are not instructive because in that era, the Federal Circuit had an established practice of vacating the judgment under review whenever the parties settled on appeal. See, e.g., Laber v. Merit Sys. Prot. Bd., 982 F.2d 519, 520 (Fed. Cir. 1992) ("When parties settle while a case is on appeal, the proper course is not to dismiss. It is to vacate the trial tribunal's decision and to remand to the trial tribunal with instructions to dismiss."). This practice is disallowed under Bancorp and is no longer in use at the Federal Circuit.

59. See, e.g., Ohio Willow Wood Co. v. Thermo-Ply, Inc., 629 F.3d 1374 (Fed. Cir. 2011) (remanding case for limited purpose of allowing district court to consider parties' settlement-related motion for vacatur); Ericsson, Inc. v. InterDigital Commc'ns Corp., 418 F.3d 1217, 1224 (Fed. Cir. 2005) ("We have reversed the district court's decision allowing Nokia to intervene to seek reinstatement of the vacated orders. ... [I]t is not necessary for us to address whether the district court's original vacatur order in light of the settlement was proper under [Bancorp].").

60. See, e.g., Tessera, Inc. v. ITC, 646 F.3d 1357, 1371 (Fed. Cir. 2011) (holding that expiration of patents during litigation caused mootness by happenstance, and applying Bancorp to vacate a portion of the ITC's final determination relating to expired patents), cert. denied, 132 S. Ct. 2702 (2012); Tafas v. Kappos, 586 F.3d 1369, 1371 (Fed. Cir. 2009) (denying vacatur because "the agency [(the losing party)] itself has voluntarily withdrawn the regulations and thus set the stage for a declaration of mootness"); Kaw Nation v. Norton, 405 F.3d 1317 (Fed. Cir. 2005) (vacating decision of Interior Board of Contract Appeals under Bancorp in light of "exceptional circumstances" arising from the potential effect of judgment on the party that objected to circumstances that caused mootness, and uncertainty regarding the Board's authority to resolve the dispute); Aqua Marine Supply v. AIM Machining, Inc., 247 F.3d 1216 (Fed. Cir. 2001) (denying vacatur where appeal was mooted by settlement). 
intervention ${ }^{61}$ must appeal from the district court's decision to grant vacatur. This is expected to be rare for two reasons. First, third-party objectors may not become aware of the grant of vacatur until it is too late to seek intervention. ${ }^{62}$ Second, motions for intervention are often unsuccessful because preserving the collateral estoppel effect of a ruling is not deemed a substantial interest that justifies intervention as of right, ${ }^{63}$ and courts are unlikely to grant permissive intervention ${ }^{64}$ in such circumstances, given their preference to have cases settle without interference by third parties. ${ }^{65}$

In view of the lack of post-Bancorp Federal Circuit precedent addressing the merits of settlement-related vacatur at the district court level, perhaps the most relevant guidance to date may be found in a few concurring opinions, most notably in Dana v. E.S. Originals, Inc. ${ }^{66}$ and Ohio Willow Wood Co. v. Thermo-Ply, Inc. ${ }^{67}$

In Dana, the plaintiff sought to invoke offensive collateral estoppel based on a non-final ruling in order to prevent the accused infringers from asserting certain

61. See, e.g., Ericsson, 418 F.3d at 1224 ("Without intervention, there is no proper party with standing to be afforded relief under Rule 60(b). Therefore, it is not necessary for us to address whether the district court's original vacatur order in light of the settlement was proper under [Bancorp].").

62. See Fisch, supra note 2, at 621 n.165 ("[I]t is rare that third parties who might benefit from the preclusive effect of a judgment will learn of the threat to the judgment in time to make their presence known to the court.").

63. FED. R. CIV. P. 24(a)(2). A third party's interest in preserving the collateral estoppel effect of a ruling is not deemed a protectable interest for purposes of intervention as of right. See, e.g., Korczak v. Sedeman, 427 F.3d 419, 420 (7th Cir. 2005) ("The opportunity to use a judgment in a suit to which one is not a party to gain an advantage in a suit to which one is a party is valuable, but the denial of the opportunity is not a sufficient injury to confer standing.”); Purcell v. BankAtlantic Fin. Corp., 85 F.3d 1508, 1513 (11th Cir. 1996) (“"The potential intervenor's] interest in the collateral estoppel effect of the jury's verdict in this case is too collateral, indirect, and insubstantial to support intervention as of right."). More generally, the relationship between intervention and Article III standing remains unsettled. See, e.g., Sokaogon Chippewa Cmty. v. Babbitt, 214 F.3d 941, 946 (7th Cir. 2000) ("[A]t some fundamental level the proposed intervenor must have a stake in the litigation. Some disagreement remains among the circuits about how Article III standing rules intersect with the requirements for Rule 24 intervention. This remains a question that the Supreme Court has not resolved." (citations omitted)); see also 6 MoORE, supra note 35, at $§ 24.03$ [2][d] ("[T]here is confusion and conflict among the federal courts regarding whether movants to intervene [as of right] must independently satisfy standing requirements in addition to the requirements of Rule 24(a)(2).”).

64. FED. R. CIV. P. 24(b)(1)(B) ("On timely motion, the court may permit anyone to intervene who ... has a claim or defense that shares with the main action a common question of law or fact.").

65. See, e.g., Purcell, 85 F.3d at 1513 (noting that "public policy values . . . are furthered by permitting parties to settle a case without the interference of interlopers"); see also FED. R. CIV. P. 24(b)(3) ("In exercising its discretion [to grant permissive intervention], the court must consider whether the intervention will unduly delay or prejudice the adjudication of the original parties' rights.").

66. 342 F.3d 1320, 1327-29 (Fed. Cir. 2003) (Dyk, J., concurring).

67. 629 F.3d 1374, 1376-77 (Fed. Cir. 2011) (Moore, J., concurring). 
defenses. ${ }^{68}$ The Federal Circuit held that the non-final ruling satisfied the legal requirements for collateral estoppel, but remanded the case for additional findings relating to its offensive (as opposed to defensive) use. ${ }^{69}$ In concurrence, Federal Circuit Judge Timothy Dyk suggested that parties who settle during district court litigation might consider moving to vacate non-final rulings so as to prevent them from having collateral estoppel effect. ${ }^{70}$ According to Judge Dyk, Bancorp posed no barrier to such an arrangement: "Bancorp did not ... address the power of the district court to vacate non-final orders pursuant to a settlement agreement. Indeed, by its terms, Bancorp does not apply to district courts but rather only to the Supreme Court and to courts of appeals. ${ }^{, 71}$ Notably, in the dataset compiled for the empirical study, Judge Dyk's concurrence in Dana was cited in the vacatur motions filed in at least 16 cases $^{72}$ (out of 79), targeting non-final rulings as well as final judgments, and it was also cited in the orders issued in 2 cases granting vacatur of non-final rulings.

In contrast to Judge Dyk's concurrence in Dana, Federal Circuit Judge Kimberly Moore's concurrence in Ohio Willow Wood suggests that Bancorp is highly relevant at the district court level, taking the view that settlement-related vacatur in the absence of "exceptional circumstances" may adversely impact the public interest. ${ }^{73}$ Ohio Willow Wood was a precedential order issued by the Federal Circuit in 2011 that formalized its practice of granting "limited remands" to allow the parties to jointly move the district court to vacate the appealed judgment in connection with a settlement. The "limited remand" practice appears to originate from the Supreme Court's suggestion in Bancorp that an appeals court, when presented with a request to vacate a district court judgment, could remand the case to allow the district court to consider vacatur. ${ }^{74}$ Although this practice has been in use at the Federal Circuit since the Bancorp decision, ${ }^{75}$ the "limited remand" orders were apparently all nonprecedential before the Ohio Willow Wood order was issued in $2011 .^{76}$

Notably, the precedential portion of the Ohio Willow Wood order did not contain any official pronouncements on whether settlement-related motions for vacatur

68. Dana, 342 F.3d at $1320-23$.

69. Id. at $1325-27$.

70. Id. at 1328 (Dyk, J., concurring) (noting that preventing non-final decisions from having collateral estoppel effect in future litigation "could perhaps be accomplished by moving to vacate the district court's earlier decision as part of the settlement").

71. Id.

72. Some motions were filed under seal, so 16 is a lower bound.

73. Ohio Willow Wood Co. v. Thermo-Ply, Inc., 629 F.3d 1374, 1376-77 (Fed. Cir. 2011) (Moore, J., concurring).

74. U.S. Bancorp Mortg. Co. v. Bonner Mall P'ship, 513 U.S. 18, 29 (1994).

75. Bancorp was decided in November 1994. The earliest post-Bancorp case (for which an opinion is electronically available on Lexis), where the Federal Circuit appears to follow Bancorp's suggestion and remands a case to a subordinate tribunal for it to consider a vacatur motion, is Dyncorp v. O'Leary, No. 94-1493, 1995 U.S. App. LEXIS 449 (Fed. Cir. Jan. 4, 1995).

76. This is based on a Lexis search of Federal Circuit opinions and orders issued between the Bancorp ruling and the Ohio Willow Wood order. 
should be granted by district courts. ${ }^{77}$ Rather, the panel unanimously decided to entrust the disposition of the vacatur motion to the discretion of the district court from which the appeal originated. ${ }^{78}$ However, one of the panel members, Judge Moore, cautioned in a concurring opinion that the Federal Circuit's limited remand order should not be "construed as an imprimatur on the joint vacatur motion." Citing Bancorp and extending its holding to the district court context, Judge Moore stressed that "[o]nly in 'exceptional circumstances' should a district court grant vacatur at the request of the litigants." ${ }^{, 80}$ Emphasizing that "patents are public rather than private rights," ${ }^{\prime}$ Judge Moore observed that "[t]he public rights are particularly vulnerable when considering vacatur following settlement," as "[t]here will be no opposing voice when the parties move for vacatur because both parties benefit." ${ }^{, 82}$ Included among the considerations Judge Moore highlighted as relevant to deciding a motion to vacate are the litigiousness of the patentee and the value of collateral estoppel in saving the courts and litigants the time and expense of relitigating issues in patent cases, which are among the most time-consuming and costly types of civil actions. ${ }^{83}$

At one level, the apparent inconsistency between Judge Dyk's concurrence in Dana and Judge Moore's concurrence in Ohio Willow Wood on the relevance of Bancorp to settlement-related vacatur at the district court level might be attributable to the fact that a non-final order was at issue in Dana, whereas Ohio Willow Wood involved a final judgment. However, as explained in greater detail in later sections, the data reveal that treating non-final rulings differently from final judgments in the context of settlement-related vacatur promote neither judicial economy nor the public interest. ${ }^{84}$ In addition, a further wrinkle in the Federal Circuit's messaging on the issue of settlement-related vacatur is introduced by its Appellate Mediation Program: ${ }^{85}$ to some parties, the Chief Circuit Mediator apparently suggests the filing of a motion to vacate certain rulings under reviewincluding invalidity rulings-in order to facilitate settlement. ${ }^{86}$ However, as a

77. See Ohio Willow Wood, 629 F.3d at 1375.

78. Id. On remand, the district court in Ohio Willow Wood denied vacatur even though it would void the parties' settlement. Ohio Willow Wood Co. v. Thermo-Ply, Inc., 769 F. Supp. 2d 1065, 1070-71 (E.D. Tex. 2011). When the parties resumed their appeal, the district court's judgment was summarily affirmed. Ohio Willow Wood Co. v. Thermo-Ply, Inc., 440 F. App'x 926 (Fed. Cir. 2011).

79. Ohio Willow Wood, 629 F.3d at 1376. (Moore, J., concurring). Viewing Judge Moore's concurrence as "placing an appellate thumb on the scale of the remand order before it reaches its destination," another member of the panel, Federal Circuit Judge Pauline Newman, wrote separately to stress that Judge Moore's concurrence was not part of the remand order. $I d$. at 1376 (Newman, J., additional views).

80. Id. (Moore, J., concurring) (citation omitted).

81. Id.

82. Id. at n.1.

83. See id. at $1376-77$.

84. See infra Parts IV.A.1-2, V.B.

85. For generalized information about the Federal Circuit's Appellate Mediation Program, see Mediation, U.S. CT. APPEAls FOR FED. CIRCUIT, http://www.cafc. uscourts.gov/mediation/mediation.html.

86. See infra note 260 and accompanying text. 
matter of official court policy, neither the Federal Circuit nor its Appellate Mediation Program takes a position on whether such motions should be granted ${ }^{87}$

Thus, in the absence of any post-Bancorp precedential opinions on the merits of settlement-related vacatur by district courts, the Federal Circuit, which currently takes no position on whether such motions should be granted, may be, nevertheless, sending district courts and litigants mixed messages on the issue through the concurrences in Dana and Ohio Willow Wood, as well as the limited remands based on the results of its Appellate Mediation Program where motions for settlementrelated vacatur may be proposed by the mediators.

\section{DESIGN OF EMPIRICAL STUDY AND SUMMARY OF RESULTS}

To critically explore the considerations highlighted in the previous sections, an empirical study was devised to investigate the following questions: (1) what is the nature of the current practice relating to the filing and disposition of motions for settlement-related vacatur? and (2) to what extent should the practice of granting settlement-related vacatur be curtailed?

To this end, various statistics were gathered to discern the relative influence of, and the interrelationships among, the three interests implicated by settlementrelated vacatur: (1) the "private" interest of the litigants in resolving their dispute; (2) the "public" interest-namely those of the general public as well as potential accused infringers - in the finality of judgments and avoiding dubious claims of patent infringement; and (3) the "judicial" interest-in particular, the court's interest in efficient case management and judicial economy. The conventional wisdom is that the relative weights of these considerations are heavily biased in favor of the intersection of the interests of the private parties and the courts, in view of the judiciary's strong preference for settlement. ${ }^{88}$ However, the mechanism and any second-order effects of this imbalance are not well documented, at least for district court patent cases. In order to craft a set of workable recommendations to correct the imbalance, or even to shift it toward the public interest, familiarity with the nature of the motions filed, their manner of disposition, and their impact is necessary. Accordingly, descriptive statistics were collected on:

(a) the types of rulings targeted for vacatur, as characterized by the subject matter, form of issuance, finality (final judgments versus interlocutory rulings), and age;

(b) the manner in which the courts rule on the motions for vacatur;

(c) case duration;

(d) the extent to which settlements are conditioned on vacatur;

(e) the characteristics of the patents affected by the rulings for which vacatur is sought (in particular, the litigation history, the type of patentee, and the technology area); and

87. Appellate Mediation Program Guidelines, U.S. Ct. ApPeAls FOR Fed. CiRcuit (Sept. 4, 2012), http://www.cafc.uscourts.gov/mediation/guidelines.html $\S 8$ ("Neither the US Court of Appeals for the Federal Circuit nor its Mediation Program takes a position of whether the motion for vacatur should be granted.").

88. See supra notes 16-19 and accompanying text. 
(f) whether intervention provides interested third parties with an adequate means of challenging a motion for settlement-related vacatur.

As described in greater detail in Part IV, courts granted vacatur in a clear majority of cases in the dataset $(78.5 \% ; 62$ out of 79$),{ }^{89}$ typically without any detailed analysis (83.9\%; 52 out of 62 granted cases), ${ }^{90}$ and with a degree of alacrity that would make it difficult for third parties to timely object and move to intervene-vacatur was granted within 4 days in more than half of the granted cases ( 35 out of 62 ), and, in $22.6 \%$ of the granted cases (14 out of 62), vacatur was granted either on the same day or without a publicly-accessible, written motion having been filed beforehand. ${ }^{91}$ Intervention motions were filed in only 4 out of the 79 cases in the dataset $(5.1 \%)$, and intervention was granted in only one case. ${ }^{92}$

However, the proportion of cases in which vacatur was denied is surprising almost a fifth of vacatur motions were denied (19\%; 15 out of 79 cases).$^{93}$ Because vacatur is not guaranteed, the filing of settlement-related vacatur motions at the district court level currently appears to function primarily as a bargaining chip during settlement negotiations, as opposed to being part of a plan by the patentee to take a wait-and-see approach to litigation. ${ }^{94}$ Indeed, the average duration of the cases where vacatur was granted (1246 days) is similar to that of the cases where vacatur was denied (1304 days) and of comparable cases where vacatur was never requested (1218 days). ${ }^{95}$

Furthermore, the data reveal that district courts appear to grant vacatur largely without regard to the litigation history of the patent, ${ }^{96}$ the type of patentee, ${ }^{97}$ whether the ruling targeted for vacatur is final or interlocutory, ${ }^{98}$ or the existence of concurrent proceedings involving the same patent in other courts. ${ }^{99}$

Overall, the results suggest that district courts in patent cases are routinely granting vacatur primarily for near-term docket management purposes-even when it would undermine judicial economy and the public interest in curtailing the anticompetitive effects of dubious infringement claims and weak patents.

\section{COMPILATION OF THE DATASET}

The empirical study reported in this Article is based upon an original "vacatur dataset" of U.S. district court patent cases filed on or after January 1, 2000, ${ }^{100}$ in

89. See infra Part IV.

90. See infra Part IV.B.

91. See infra Part IV.F.

92. See infra Part IV.F.

93. See infra Part IV.

94. See infra Part IV.C.

95. See infra Part IV.C.

96. See infra Part IV.E.1.

97. See infra Part IV.E.2.

98. See infra Part IV.A.2.

99. See infra Part IV.E.1.

100. The IPLC database, which was the primary source of cases for this study, contains patent cases filed beginning January 1, 2000. Stanford IP Litigation Clearinghouse, supra 
which a joint or unopposed ${ }^{101}$ settlement-related ${ }^{102}$ motion for vacatur was filed and decided $^{103}$ between January 1, 2006, and January 3, 2011, where the motion targeted at least one of the following four types of rulings: (1) claim construction, (2) noninfringement, (3) invalidity, or (4) unenforceability. A total of 79 cases were found. ${ }^{104}$

The subject matter of the rulings targeted for vacatur was limited to the four listed above because of the public's interest in removing the burdens on commerce and competition imposed by patents that are invalid, unenforceable, or not infringed. While there are other types of rulings for which settlement-related vacatur might be requested, such as orders relating to remedies or sanctions, they were not included in the dataset because their impact tends to be largely localized to the parties and their counsel, rather than affecting the patent itself.

In other words, the subject-matter restriction for the dataset focuses on whether the patentee seeks to vacate a ruling that would somehow impair the extent to which a patent may be repeatedly wielded against the public. In addition to invalidity and unenforceability rulings, claim construction ${ }^{105}$ and noninfringement rulings were included because they enhance the public notice function of a patent by providing notice of which products may fall outside the scope of the claims. Claim construction and noninfringement rulings are especially important where the potential accused products in a given industry (1) comply with a technical standard (e.g., any Wi-Fi-compatible device may infringe a patent covering the Wi-Fi standard); (2) possess a material feature that is implemented in a substantially similar manner across products made by different manufacturers (e.g., any smartphone that unlocks when a user slides a finger across the touchscreen could infringe a patent covering that interface feature); or (3) are essentially identical (e.g., generic drugs).

In addition to subject matter constraints, the rulings were further restricted to those that could potentially be accorded collateral estoppel effect. To this end, nonfinal, interlocutory rulings, such as claim constructions and partial summary judgment rulings, were counted in addition to final judgments because non-final

note 8 .

101. Settlement-related motions for vacatur that are actually opposed by one of the settling parties are extremely rare. Such motions were not counted for this Article, which focuses on the more common yet problematic situation where vacatur is requested and there is no opposing voice, other than from a third-party objector.

102. The dataset excludes cases where the only item targeted is a ruling that warrants vacatur on a ground independent from facilitating settlement. For example, if the sole item listed in the vacatur motion is a judgment that warrants vacatur under Fed. R. Civ. P. 60(b)(5) because the judgment was based on an earlier decision that has since been reversed or vacated, then that case was not included in the dataset.

103. For completeness, cases in which the motion was subsequently withdrawn were also included in the dataset.

104. The completeness of the dataset is necessarily limited by the completeness of the data sources (IPLC, Westlaw, and Docket Navigator) and the search functions used to compile the dataset.

105. In coding the dataset, a claim construction ruling that was targeted for vacatur was presumed to contain at least one construction that the patentee perceived as unfavorable. Further, it was assumed that a patentee would not agree to vacate a claim construction ruling that it considered wholly beneficial. 
rulings have been accorded collateral estoppel effect in some cases. ${ }^{106}$ Also, the rulings of noninfringement, invalidity, and unenforceability that were counted for the purposes of the dataset were those "actually decided" on the merits, such as the grant of an accused infringer's motion for summary judgment (as opposed to a denial of a motion). ${ }^{107}$ Claim construction rulings, which are pronouncements by the court on the meaning of claim terms, ${ }^{108}$ were counted without regard to the form in which they were delivered by the court (whether in a standalone order or in a hearing transcript). Finally, the dataset does not include cases where the only item targeted in the vacatur motion is a stipulated judgment entered solely to facilitate appeal, because such stipulations are not usually deemed "actually litigated" for the purpose of invoking collateral estoppel. ${ }^{109}$

With respect to temporal restrictions, the five-year time span of the vacatur dataset—January 1, 2006 to January 3, 2011—was chosen to minimize any artifacts in the results that might be introduced as a result of the limitations of the data sources and changes in the relevant case law. Specifically, January 1, 2006, was chosen as the starting date because: (1) the primary source of patent case data for this empirical study, the IPLC, starts with cases that were filed in $2000,{ }^{110}$ such that beginning the dataset in 2006 would minimize any artifacts attributable to the absence of any pre-2000 cases; ${ }^{111}$ (2) the Federal Circuit's Dana decision with Judge Dyk's concurrence was issued in $2003 ;{ }^{112}$ and (3) the Federal Circuit began

106. See, e.g., TM Patents L.P. v. IBM Corp., 72 F. Supp. 2d 370, 375-79 (S.D.N.Y. 1999) (according collateral estoppel effect to claim construction order); see also Dana v. E.S. Originals, Inc., 342 F.3d 1320, 1323-25 (Fed. Cir. 2003) (applying Eleventh Circuit law in holding that partial summary judgment orders satisfied legal prerequisites for applying collateral estoppel).

107. See, e.g., Kay-R Elec. Corp. v. Stone \& Webster Constr. Co., 23 F.3d 55, 59 (2d Cir. 1994) ("[I]t is clear that for collateral estoppel to bar a party on an issue, the issue in dispute must actually have been litigated and actually decided. . . . The denial of a motion for summary judgment is not such.”).

108. See Markman v. Westview Instruments, Inc., 517 U.S. 370, 372 (1996) (holding that "the construction of a patent, including terms of art within its claim, is exclusively within the province of the court").

109. See, e.g., United States v. Young, 804 F.2d 116, 118 (8th Cir. 1986) (“A fact established in prior litigation not by judicial resolution but by stipulation has not been 'actually litigated' and thus is the proper subject of proof in subsequent proceedings." (citation omitted)). The Federal Circuit further refined this rule in Hartley v. Mentor Corp., 869 F.2d 1469, 1471 (Fed. Cir. 1989), holding that, in determining whether issue preclusion may arise from a stipulated judgment, "the primary consideration is the intent of the parties."

110. See supra note 100 .

111. That is, the vacatur dataset would not include any pre-2000 cases that were pending on or after January 1, 2006. The number of omitted pre-2000 cases having a settlementrelated motion for vacatur that would satisfy both the subject matter and time period restrictions for the vacatur dataset is expected to be negligible because patent cases pending longer than six years are outliers. For example, out of the 1756 cases filed in 1997, only 66 (4\%) had a duration of five or more years. Kesan \& Ball, supra note 11, at 282, tbl.11. Similarly, out of the 2081 cases filed in 2000, only $62(2.5 \%)$ were pending on February 15 , 2006. Id. at 282, tbl.11, n.253.

112. Dana v. E.S. Originals, Inc., 342 F.3d 1320, 1320 (Fed. Cir. 2003). 
its Appellate Mediation Program in late 2005. ${ }^{113}$ As for the end date of the dataset, January 3, 2011, was chosen because the Federal Circuit issued its precedential Ohio Willow Wood "limited remand" order on January 4, 2011, such that limiting the vacatur dataset to filings and rulings on or before January 3, 2011, would allow the data to be analyzed without the need to factor in the influence, if any, of that order or Judge Moore's concurrence. ${ }^{114}$

The 79 district court cases ${ }^{115}$ in the dataset were identified primarily using the IPLC, supplemented with searches in Westlaw and Docket Navigator. ${ }^{116}$ The IPLC allows Boolean searching of individual docket entries, ${ }^{117}$ as well as certain case documents-primarily complaints, opinions, orders, and judgments. A supplemental search was also performed in Westlaw, ${ }^{118}$ which has a collection of searchable civil trial filings. As a further check, a search was performed on Docket Navigator, which contains a substantial collection of searchable district court orders in the more recent cases. ${ }^{19}$

Sources of underinclusiveness in the dataset include the failure to discover cases where the settlement-related vacatur motion was filed under seal with uninformative docket text, and the resulting ruling by the court does not reveal the nature of the relief requested in the sealed motion (such as where the ruling refers to the motion only by the docket number). Similarly, if the motion was presented informally or off-the-record at a hearing or at a conference-and the court provided only an oral ruling - then such cases would have been missed as well. Where both the motion and the court's ruling are obscured from the public in this manner, it is likely that vacatur was denied rather than granted, because the fact that a docket item has been vacated would need to be made clear in the public record. As a result,

113. Appellate Mediation Program Guidelines, supra note 87 ("The United States Court of Appeals for the Federal Circuit established an appellate mediation program pursuant to Federal Rule of Appellate Procedure 33, which commenced on October 3, 2005.”).

114. Because the Ohio Willow Wood order does not address the merits of the vacatur motion, see Ohio Willow Wood Co. v. Thermo-Ply, Inc., 629 F.3d 1374, 1375 (Fed. Cir. 2011), and Judge Moore's concurrence is not binding precedent, see id. at 1375-76 (Newman, J., additional views), the practice of settlement-related vacatur in district court patent cases is unlikely to dramatically change on or after January 4, 2011, in the absence of a precedential Federal Circuit decision evaluating the merits of a district court's ruling on a motion for settlement-related vacatur. Nevertheless, the Ohio Willow Wood case may prompt some district courts to analyze settlement-related vacatur motions more closely, and the empirical study presented in this Article endeavors to provide information that might be helpful in evaluating the appropriateness of granting vacatur in a given case.

115. Transferred cases and consolidated cases were counted only once. For consolidated cases, a single "representative" case was coded for the group, where the case chosen for coding was the oldest case that served as the primary docket (usually the "lead" case) involving any of the patents that would benefit from the grant of vacatur.

116. Out of the 79 cases in the dataset, 74 were found using the IPLC and 5 were found using Westlaw. After the IPLC and Westlaw searches, a further search was also performed on Docket Navigator; no additional cases were found on Docket Navigator that were not previously discovered.

117. Appendix A provides details of the searches performed on the IPLC.

118. Appendix B provides details of the searches performed on Westlaw.

119. Appendix $\mathrm{C}$ provides details of the searches performed on Docket Navigator. 
the risk of undercounting is greater for the cases in which vacatur was denied than in the cases in which it was granted.

\section{ANALYSIS OF RESULTS}

For the 79 cases in the dataset, motions for vacatur were granted in 62 cases $(78.5 \%),{ }^{120}$ denied in 15 cases $(19 \%)$, and withdrawn by the parties in 2 cases $(2.5 \%) .{ }^{121}$

\section{A. Profile of Rulings Targeted for Vacatur}

\section{Subject Matter and Form of Issuance}

Table 1 tallies the number of cases in the dataset where the vacatur motion targeted at least one of the four types of rulings affecting patent scope, validity, or enforceability:

\section{Table 1: Rulings Targeted for Vacatur}

\begin{tabular}{lcc} 
Substance of Ruling & $\begin{array}{c}\text { Number } \\
\text { of Cases }\end{array}$ & $\begin{array}{c}\text { \% of Cases } \\
\text { (out of 79) }\end{array}$ \\
\hline \hline Claim Construction & 40 & $50.6 \%$ \\
Noninfringement & 32 & $40.5 \%$ \\
Invalidity & 25 & $31.6 \%$ \\
Unenforceability & 5 & $6.3 \%$
\end{tabular}

In Table 1, the total number of cases (and therefore the percentage) exceeds 79 (or 100\%) because a vacatur motion in a given case may target more than one type of ruling. To be clear, the numbers in Table 1 do not list the absolute number of rulings targeted; rather, Table 1 lists the number of cases in which the vacatur motion targets a specific type of ruling. For example, if the vacatur motion in a single case targets three separate rulings of noninfringement for different sets of patents, the contribution of that case to Table 1 is to increment the "Noninfringement" row by one, not three. By counting the number of cases rather than the absolute number of rulings targeted for vacatur, the larger, complex cases with multiple rulings are not disproportionally represented in the dataset.

120. This includes 2 cases in which the parties and the court attempted to achieve the substantive effect of vacatur-namely, the elimination of any potential collateral estoppel effect - by having the court issue an order declaring that the ruling was limited to that case. For the purpose of reporting data and statistical analysis, these cases were counted as instances in which vacatur was granted.

121. In the 2 cases where the parties withdrew their motions, the parties subsequently settled. 
That claim construction rulings ${ }^{122}$ were targeted for vacatur in approximately half of the cases in the dataset $(50.6 \%$; 40 out of 79 cases) appears to reflect their dispositive role in determining patent liability issues. ${ }^{123}$ Indeed, a claim construction ruling was the sole item targeted for vacatur in $31.6 \%$ of the cases in the dataset ( 25 out of 79 cases). The targeting of claim construction rulings for vacatur is noteworthy because the extent to which they may be accorded collateral estoppel effect remains unsettled: the Federal Circuit currently applies regional circuit law governing collateral estoppel to evaluate the preclusive effect of claim construction rulings, ${ }^{124}$ and has not yet considered the issue directly on the merits as a matter of Federal Circuit law. ${ }^{125}$ In addition, some district courts have accorded collateral estoppel effect to claim construction rulings, ${ }^{126}$ while others have not. ${ }^{127}$

122. Because claim constructions often underlie, and are incorporated into, rulings on patent liability issues (such as noninfringement), claim construction rulings were counted as a distinct item for vacatur only if the motion made clear that it was the sole reason a specific ruling or docket item was being targeted for vacatur. For example, if a case does not have a standalone claim construction order, and the vacatur motion targets a ruling granting summary judgment of noninfringement that construes several claim terms as part of its analysis, the motion was coded as targeting a noninfringement ruling only. Conversely, if a standalone claim construction order contained a ruling that a claim term was indefinite, it was coded only as a claim construction ruling and not also as an invalidity ruling.

123. See Peter S. Menell, Lynn H. Pasahow, James Pooley \& Matthew D. Powers, Patent Case Management Judicial Guide 2-6 (2009), available at http://papers. ssrn.com/sol3/papers.cfm?abstract_id=1328659 ("[T]he structure and operation of an accused device is often undisputed, so that determination of infringement will collapse into a question of claim construction. . . Claim construction is the foundation for analysis of both infringement (has the patentee claimed broadly enough?) and invalidity (has the patentee claimed too much?)." (citation omitted)).

124. See, e.g., RF Delaware, Inc. v. Pac. Keystone Techs., Inc., 326 F.3d 1255, 1260-61 (Fed. Cir. 2003) (analyzing Eleventh Circuit law and denying application of collateral estoppel to claim construction ruling).

125. Whether a claim construction ruling may be accorded collateral estoppel effect is an issue for which at least two petitions for interlocutory appeal were filed in recent years. In 2009, the Federal Circuit granted a petition for interlocutory appeal on this issue. See Shire LLC v. Sandoz, Inc., 345 F. App'x 535, 535 (Fed. Cir. 2009). However, the parties settled shortly thereafter and dismissed the appeal. See Shire LLC v. Sandoz, Inc., 368 F. App'x 116 (Fed. Cir. 2009). In 2010, another petition for interlocutory review was filed, but the Federal Circuit denied that petition. See ICU Med., Inc. v. Rymed Techs., Inc., 364 F. App'x 622, 623 (Fed. Cir. 2010).

126. See, e.g., TM Patents, L.P. v. IBM Corp., 72 F. Supp. 2d 370, 377 (S.D.N.Y. 1999) ("[T]he results of the Markman hearing in the [prior] action were sufficiently 'final' to permit application of collateral estoppel—even though the matter to which they were necessary was never reduced to a final judgment after verdict."); see also Edberg v. CPIThe Alternative Supplier, Inc., 156 F. Supp. 2d 190, 196 (D. Conn. 2001) ("[A]s the TM Patents court noted, the mere fact that plaintiffs settled the prior case does not give this Court's prior [claim construction] rulings any less preclusive effect."); Abbott Labs. v. Dey, L.P., 110 F. Supp. 2d 667, 669-71 (N.D. Ill. 2000) (analyzing requirements for issue preclusion and concluding that they were satisfied for purpose of according preclusive effect to prior claim construction ruling).

127. See, e.g., Kollmorgen Corp. v. Yaskawa Elec. Corp., 147 F. Supp. 2d 464, 468-70 
In view of this uncertainty, the data suggest that patentees appear to be taking the risk-averse route by seeking vacatur of claim construction rulings.

Turning to the noninfringement, invalidity, and unenforceability rulings, Table 2 provides a matrix of the substance of the ruling and its form of issuance. Each cell lists the number of cases and its corresponding percentage of the dataset (out of 79 cases): ${ }^{128}$

\section{Table 2: Rulings and Form of Issuance Targeted for Vacatur (\# of cases; \% of dataset ( 79 cases))}

\begin{tabular}{lccc} 
Form of Issuance & Noninfringement & Invalidity & Unenforceability \\
\hline \hline $\begin{array}{l}\text { Grant of Summary } \\
\text { Judgment }\end{array}$ & $28(35.4 \%)$ & $21(26.6 \%)$ & $2(2.5 \%)$ \\
Bench Trial & $1(1.3 \%)$ & 0 & $2(2.5 \%)$ \\
Jury Verdict & $2(2.5 \%)$ & $3(3.8 \%)$ & 0 \\
Grant of JMOL & $1(1.3 \%)$ & $2(2.5 \%)$ & $1(1.3 \%)$
\end{tabular}

The column totals in Table 2 may exceed those of the rows in Table 1 because a vacatur motion in a single case may target a specific type of ruling across different forms of disposition. For example, if a vacatur motion targets a ruling granting summary judgment of invalidity as well as a jury verdict containing a finding of invalidity, they are counted separately in Table 2. As shown in Table 2, the most common type of disposition targeted for vacatur is the grant of summary judgment of noninfringement (35.4\% of cases), followed by the grant of summary judgment of invalidity (26.6\% of cases). The frequency of each of the remaining types of dispositions, many of which involve trials, is in the low single digits.

The data from Tables 1 and 2 suggest that the timing of settlements in cases where settlement-related vacatur is requested may not be appreciably different from that of the general population of patent cases that have progressed to a point where the court has issued a substantive ruling regarding the merits of the case: settlement discussions generally begin in earnest after the issuance of a claim construction order or a ruling on a motion for summary judgment but before trial. ${ }^{129}$ Indeed, as

(W.D. Va. 2001) (denying collateral estoppel effect to claim construction order); see also Graco Children's Prods., Inc. v. Regalo Int'l, LLC, 77 F. Supp. 2d 660, 663 (E.D. Pa. 1999) ("[T]he [Supreme] Court in Markman did not guarantee that collateral estoppel would apply in every case, and this Court will not extend the Supreme Court ruling to mean as much, especially where, as here, the circumstances of the instant action require that a different result be reached.").

128. The entire vacatur dataset contains 79 cases, but Table 2, which specifically focuses on the noninfringement, invalidity, and unenforceability rulings targeted for vacatur, does not include the 25 cases in the dataset where the sole item targeted for vacatur was a claim construction ruling.

129. Cf. MENELl ET AL., supra note 123 at 2-7 ("One argument in favor of early, separate claim construction is that it may facilitate settlement. . . [I]t may be fruitful to schedule a 
discussed in greater detail in Part IV.C, the average duration of the cases in the vacatur dataset is similar to the average duration of the cases in the general population where the court has reached the merits of the patent liability issues. ${ }^{130}$

\section{Final Judgments Versus Interlocutory Orders}

Twice as many motions for vacatur were filed before the entry of final judgment than afterwards, as shown in Table $3:^{131}$

Table 3: Finality and Disposition of Vacatur Motions

\begin{tabular}{lcc} 
Disposition & $\begin{array}{c}\text { Motion Filed Before } \\
\text { Final Judgment } \\
N=50(\% \text { of } 50)\end{array}$ & $\begin{array}{c}\text { Motion Filed After } \\
\text { Final Judgment } \\
N=25(\% \text { of } 25)\end{array}$ \\
\hline \hline Vacatur Granted & $41(82 \%)$ & $19(76 \%)$ \\
Vacatur Denied & $9(18 \%)$ & $6(24 \%)$
\end{tabular}

Notably, motions to vacate interlocutory orders and final rulings were granted at comparable rates $(82 \%$ versus $76 \%)$ in the dataset. ${ }^{132}$ This result is somewhat surprising because vacatur after the entry of final judgment under Rule 60(b)(6) requires a showing of "extraordinary circumstances,",133 whereas a district court has fewer restrictions in vacating an interlocutory order under Rule 54(b). ${ }^{134}$ That final

settlement conference to follow shortly after issuance of a claim construction order.").

130. See infra Part IV.C.

131. This Table does not include 4 cases from the dataset: 2 cases where the parties withdrew their vacatur motions, and 2 cases where the vacatur motion was filed after the case was remanded upon completion of an appeal.

132. The difference in the grant rates is not statistically significant: using Fisher's exact test, the two-tailed p-value is 0.553 . Fisher's exact test is useful for significance testing where the dataset is relatively small such that the Chi-square test may not return accurate results. Rick Routledge, Fisher's Exact Test, in 3 ENCYClOPEDIA OF BiOSTATISTICS 1961, 1961-62 (Peter Armitage \& Theodore Colton eds., 2d ed. 2005), available at http://online library.wiley.com/doi/10.1002/0470011815.b2a10020/full. The significance levels used throughout this Article are as follows: if the p-value is less than $0.05(5 \%)$, the result is deemed statistically significant; if it is less than $0.01(1 \%)$, the result is deemed highly statistically significant. DAVId Freedman, Robert PisAni \& Roger PuRves, Statistics 482 (4th ed. 2007). Two-tailed p-values are reported in this Article because it is more conservative (that is, less likely to indicate statistical significance) than a one-tailed result. See generally R. MARK SiRKIn, StATISTICS FOR tHe Social SCIENCES 210-12 (3d ed. 2006).

133. See supra notes 35 \& 54. See, e.g., Liljeberg v. Health Servs. Acquisition Corp., 486 U.S. 847, 863-64 (1988) (observing that Rule 60(b)(6) "does not particularize the factors that justify relief, but . . . it provides courts with authority 'adequate to enable them to vacate judgments whenever such action is appropriate to accomplish justice,' while also cautioning that it should only be applied in "extraordinary circumstances"" (citations omitted)).

134. See, e.g., Avondale Shipyards, Inc. v. Insured Lloyd's, 786 F.2d 1265, 1269 (5th Cir. 1986) ("Not only is [an interlocutory] order not appealable, but it remains within the 
judgments are being vacated at a rate close to that of interlocutory orders suggests that district courts are disproportionately prioritizing settlements over the public's interest in the finality of judgments and the preclusive value of precedent. Moreover, the $82 \%$ grant rate of motions targeting interlocutory orders appears to be a disproportionally high rate of "revising" a ruling under Rule 54(b): outside of the context of settlement-related vacatur, district courts very rarely grant motions for reconsideration that seek to amend an interlocutory ruling. ${ }^{135}$

In short, the high rate of granting vacatur for both interlocutory and final rulings is a likely indication that district courts are elevating near-term docket management concerns — which may be readily alleviated by settlement—over long-term judicial economy and the public interest (particularly those of non-parties). This is a recurring pattern in the data, as illustrated in the rest of Part IV.

\section{Age of Rulings Targeted for Vacatur}

The impact of vacatur on third parties and other proceedings is likely to be greater the longer a ruling has remained in force. For example, if a ruling in one case is based on according collateral estoppel effect to a prior ruling in a different case, then the vacatur of that prior ruling could allow the patentee to seek vacatur of the later ruling under Rule 60(b)(5). ${ }^{136}$ In addition to concurrent litigation, there may be ripple effects in various non-judicial contexts, including proceedings at the U.S. Patent \& Trademark Office and arbitration.

Accordingly, data on the "age" 137 of the rulings targeted for vacatur were collected, as summarized in the table below:

plenary power of the district court to revise or set aside in its sound discretion without any necessity to meet the requirements of Fed. R.Civ.P. 60(b)."); see also Persistence Software, Inc. v. Object People, Inc., 200 F.R.D. 626, 627 (N.D. Cal. 2001) ("The standard for granting a motion to vacate under Rule 54(b) is less rigid than that under Rule 60(b) governing vacation of final judgments.”). But see Siemens Med. Sys., Inc. v. Nuclear Cardiology Sys., Inc., 945 F. Supp. 1421, 1435 (D. Colo. 1996) (“Although Rule 54(b) provides that an order that is not explicitly made final is subject to later revision, it would be pedantic to contend that all interlocutory orders are therefore 'tentative' in any real sense.").

135. 11 MOORE, supra note 35, at $\S 56.124[1]$ ("Motions for reconsideration of interlocutory summary judgment rulings are rarely granted . ...").

136. FED. R. Civ. P. 60(b)(5) provides: "On motion and just terms, the court may relieve a party or its legal representative from a final judgment, order, or proceeding for the following reason[]: ... . [If] the judgment ... is based on an earlier judgment that has been reversed or vacated ...." (emphasis added).

137. The age of the targeted ruling associated with each case was calculated as the difference between the date on which the targeted ruling was issued and the date of the vacatur motion. If there were multiple rulings targeted for vacatur in a single motion, the date of the oldest ruling was used.

The date of the vacatur motion was coded as the first date on which the parties moved for vacatur. In a few cases, more than one version of the vacatur motion was filed because the parties were gauging the district court's willingness to grant vacatur by initially requesting an "indicative ruling" (under FED. R. CIV. P. 62.1) in connection with a potential "limited remand" during appeal (under FED. R. APP. P. 12.1), and then filing a "formal" vacatur motion on remand. In those cases, the date of the motion for the indicative ruling was coded as the date of the vacatur motion because it was the first formal motion in the 
Table 4: Age of Rulings Targeted in Vacatur Motions (in days)

\begin{tabular}{lcccc} 
& $\begin{array}{c}\text { All Cases } \\
\text { in Dataset } \\
N=79\end{array}$ & $\begin{array}{c}\text { Vacatur } \\
\text { Granted } \\
N=62\end{array}$ & $\begin{array}{c}\text { Vacatur } \\
\text { Denied } \\
N=15\end{array}$ & $\begin{array}{c}\text { Motion } \\
\text { Withdrawn } \\
N=2\end{array}$ \\
\hline \hline $\begin{array}{l}\text { Range } \\
\text { (Low/High) }\end{array}$ & $6 / 1219$ & $6 / 1219$ & $16 / 853$ & $648 / 670$ \\
Average & 329 & 339 & 242 & 659 \\
Median & 227 & 240 & 152 & 659 \\
Std. Dev. & 287 & 292 & 252 & 15.6
\end{tabular}

In the dataset, the average age of a ruling that was targeted for vacatur is 329 days (median: 227 days), which provides a substantial period of time for the ruling to be discovered by third parties and cited in other proceedings. Although there were too few cases where vacatur was denied $(N=15)$ to allow a comparison of the average ages for statistical significance, ${ }^{138}$ it is notable that the average age of the targeted rulings where vacatur was denied ( 242 days; median: 152 days) is actually shorter than the average age where vacatur was granted (339 days; median: 240 days). One possible explanation for this result is that a court might be disinclined to vacate a substantive decision so soon after having invested considerable resources in its preparation, whereas after the passage of time, the court may be more receptive to granting vacatur as a result of "hedonic adaptation." 139

However, the longer the delay in vacating a ruling after its issuance, the greater the likelihood of potential disruption to other proceedings-especially if the ruling has been accorded collateral estoppel effect in another case. Indeed, the fact that collateral estoppel was successfully invoked in a parallel proceeding may be one of the reasons behind a patentee's desire to seek vacatur of the prior ruling underlying the invocation of collateral estoppel: once the prior ruling is vacated, the patentee can then move under Rule 60(b)(5) to secure vacatur of the disposition in the

public record that put the court and any interested third parties on notice of the parties' desire for vacatur. In one case where the patentee filed two vacatur motions in close succession in the course of settling with different defendants in a multi-defendant suit, only the first vacatur motion was counted and coded because both vacatur motions targeted the same set of substantive rulings.

138. A two-sample t-test is commonly used to compare the averages of two sets of data for statistical significance. See generally SIRKIN, supra note 132, at 271-74. In order for the t-test to produce reliable results, each constituent set should contain at least thirty observations. Carmen R. Wilson VanVoorhis \& Betsy L. Morgan, Understanding Power and Rules of Thumb for Determining Sample Sizes, 3 Tutorials QuantiTative Methods FOR PSYCHOL. 43, 48 tbl.3 (2007), available at http://www.tqmp.org/Content/vol032/p043/p043.pdf.

139. "Hedonic adaptation" refers to the tendency to return to a baseline emotional state after a positive or a negative experience. Shane Frederick \& George Loewenstein, Hedonic Adaptation, in Well-Being: The Foundations of Hedonic Psychology 302, 302 (Daniel Kahneman, Ed Diener \& Norbert Schwarz eds., 1999) ("Hedonic adaptation refers to a reduction in the affective intensity of favorable and unfavorable circumstances.”). 
parallel proceeding that resulted from the application of collateral estoppel. ${ }^{140} \mathrm{In}$ this manner, the patentee can strip from a court in a concurrent case the efficiency gains from having applied collateral estoppel, so as to place that court in a position where it may need to readjudicate the same issues. Accordingly, a court can minimize the prejudice to third parties and other courts by denying vacatur based on the "age" of the ruling targeted for vacatur, or if there is a concurrent proceeding involving the same patent.

\section{B. Manner of Disposition of Vacatur Motion}

When ruling on vacatur motions, courts generally granted or denied the motion as a whole, even though the nature and scope of the relief sought in the 79 vacatur motions varied in type and number. The number of docket items targeted for vacatur in a given motion ranged from 1 to 20 , with an average of 2 docket items targeted per motion. A vacatur motion will often target multiple items on the docket because the patentee will seek to vacate not only a specific ruling, but also any related items. For example, if a patentee desires to eliminate any preclusive effect associated with a noninfringement ruling, the motion might list not only the associated memorandum opinion granting summary judgment of noninfringement, but also the minute order of the hearing during which the court provided a tentative ruling, the opinion denying the patentee's motion for reconsideration, and the entry of judgment in favor of the accused infringer based on the noninfringement ruling. Furthermore, in 11 out of 79 cases (13.9\%), the vacatur motions also targeted affirmative rulings ${ }^{141}$ that were adverse to the accused infringer on an issue of patent liability, in addition to the items that the patentee targeted.

A comparison between the relief requested in the motion for vacatur and the court's ruling on the motion was possible in 73 out of the 79 cases in the dataset: ${ }^{142}$

140. For example, in CollegeNET, Inc. v. XAP Corp., No. 3:03-cv-01229-BR (D. Or.), the patentee, CollegeNET, moved for settlement-related vacatur of an invalidity judgment that had been accorded collateral estoppel effect in a concurrent case, CollegeNET, Inc. $v$. ApplyYourself, Inc., No. 3:02-cv-00484-HU (D. Or.). Opinion and Order at 2-6, CollegeNET, Inc. v. XAP Corp., No. 3:03-cv-01229-BR (D. Or. June 8, 2009), ECF No. 927. After the $X A P$ court granted vacatur, $i d$. at 2, the patentee filed a Rule 60(b)(5) motion in the ApplyYourself case to vacate an order granting summary judgment of invalidity on the ground that it relied on the now-vacated XAP judgment. Memorandum in Support of Unopposed Renewed Motion to Vacate Interlocutory Order Granting Defendant's Motion for Summary Judgment of Invalidity Based on Collateral Estoppel and to Enter Agreed Consent Judgment at 2, CollegeNET, Inc. v. ApplyYourself, Inc., No. 3:02-cv-00484-HU (D. Or. June 10, 2009), ECF No. 741. The ApplyYourself court granted the Rule 60(b)(5) motion. Order at 2-3, CollegeNET, Inc. v. ApplyYourself, Inc., No. 3:02-cv-00484-HU (D. Or. June 12, 2009), ECF No. 743.

141. By "affirmative ruling," the author refers to a disposition granting (rather than denying) a motion, a jury verdict, or the entry of judgment.

142. In 6 cases, a comparison could not be made: in 2 cases, the parties withdrew their vacatur motion; and in 4 cases, a written motion was not filed prior to the court's ruling, such that it could not be determined whether the court modified the relief sought. (There were a total of 6 cases in which a written motion was not formally filed, but in 2 of those cases, it was possible to ascertain that the court did not modify the relief sought because the 
the court denied the motion as a whole in 15 cases, granted the motion in full without modification in 55 cases, and granted the motion with modifications in 3 cases. In 2 of the 3 cases where the relief requested was modified, the court's ruling actually increased the number of items vacated, ${ }^{143}$ and in the remaining case, the court provided a substitute form of relief by limiting the effect of the targeted ruling to the case so as to achieve the effect of vacatur in extinguishing any preclusive effect of the targeted ruling beyond the case. ${ }^{144}$ In short, of the 58 cases where the ruling granting vacatur (or its equivalent) could be compared with the original relief sought in the motion, the court granted less than the original relief requested, albeit slightly, in only a single case.

Furthermore, when courts decided vacatur motions, they often did so without issuing a fully reasoned opinion explaining the decision to grant or deny vacatur, as shown in Table 5 below:

Table 5: Manner of Disposition of Vacatur Motions ${ }^{145}$

\begin{tabular}{lcc} 
Manner of Disposition & $\begin{array}{l}\text { Vacatur } \\
\text { Granted } \\
N=62\end{array}$ & $\begin{array}{l}\text { Vacatur } \\
\text { Denied } \\
N=15\end{array}$ \\
\hline \hline Proposed order adopted without material changes & 34 & 0 \\
\hline Proposed order modified & $1^{146}$ & $3^{147}$ \\
\hline $\begin{array}{l}\text { [Proposed order not used] Ruling did not contain } \\
\text { substantive explanation or analysis }\end{array}$ & 17 & 5 \\
\hline $\begin{array}{l}\text { [Proposed order not used] Ruling contained } \\
\text { substantive explanation or analysis }\end{array}$ & 10 & 7 \\
\hline
\end{tabular}

When granting vacatur, district courts provided a substantive, ${ }^{148}$ reasoned opinion in only $16.1 \%$ of cases ( 10 out of 62 grants). Even where the settlementrelated vacatur motion was filed after the entry of final judgment-which requires a showing of "extraordinary circumstances" under Rule 60(b)(6) ${ }^{149}$ - courts provided substantive explanations in only 4 out of 19 cases $(21.1 \%)$ where vacatur was

court's order was the parties' proposed order, signed without substantive modification.)

143. In these cases, the court's ruling included additional related docket items for vacatur, such as a prior version of the targeted ruling, a related minute order, and an order entering judgment that was based on the targeted ruling. The supplementation appears to have been made in furtherance of the relief requested by vacating all vestiges of the targeted ruling and its effects. It is unknown whether the court added the related items sua sponte or had been informally asked to do so by the parties after the motion was filed.

144. In coding the dataset, this was counted as a grant of vacatur.

145. This table does not include the 2 cases where the vacatur motion was withdrawn.

146. The court changed the request for vacatur to a request to limit the ruling to the case, which has the substantive effect of vacatur.

147. In these cases, the court converted the proposed order to one that denied vacatur, such as by replacing the word "grant" with "deny" or striking relevant parts.

148. In coding the dataset, a ruling contained "substantive" analysis if it went beyond a conclusory statement on the appropriateness of the ruling.

149. See supra notes $35 \& 54$. 
granted after final judgment. By contrast, when vacatur was denied, the court issued a substantive ruling $46.7 \%$ of the time ( 7 out of 15 denials). This disparity in the rate of courts providing substantive explanations when granting versus denying vacatur $(16.1 \%$ versus $46.7 \%)$ is statistically significant. ${ }^{150}$

This is basically the inverse of the scenario contemplated by Bancorp, which provides that the grant of vacatur based on settlement is deemed an "extraordinary remedy" that is justified only under "exceptional circumstances." data suggest that district courts are effectively treating the denial of vacatur as the exceptional case that warrants reasoned justification. One possible explanation for this result may be that the primary audience for a substantive opinion setting forth the bases for denying vacatur may be the appellate court in the event the parties appeal (or resume their appeal after a "limited remand"), so as to provide additional context of the circumstances under which the parties are seeking appellate review. ${ }^{152}$

Unfortunately, there are too few cases in the dataset from which to draw any firm conclusions as to whether the Federal Circuit might accord greater deference to the district court's judgment when an appeal is prompted by the district court's reasoned refusal to vacate. Nevertheless, it is worth noting that only 2 cases in the dataset were appealed after vacatur was denied, and both of those denials were delivered through substantive opinions; on appeal, neither case resulted in a reversal or a remand. ${ }^{153}$ In addition, when the district court in Ohio Willow Wood denied vacatur during the limited remand, it explained its denial in a thoroughlyreasoned opinion; when the appeal resumed, the Federal Circuit summarily affirmed the judgment. ${ }^{154}$ Although these three cases may not necessarily denote a trend, they do provide a starting point for future research.

\section{Vacatur and Case Duration}

In Bancorp, the Supreme Court observed that settlement-related vacatur "may deter settlement at an earlier stage" whereby "[ $s]$ ome litigants, at least, may think it worthwhile to roll the dice rather than settle . . . if, but only if, an unfavorable outcome can be washed away by a settlement-related vacatur." 155 However, at the

150. Using Fisher's exact test, the two-tailed p-value is 0.017 .

151. See supra notes $46-48$ and accompanying text.

152. See Hoffman et al., supra note 18, at 703-04 ("When reversing trial court work, appellate judges often comment on the lack of a written opinion. . . Although empirical evidence on whether opinions reduce reversal rates is at best ambiguous, it is possible that trial judges believe that writing can protect them from shame." (footnotes omitted)).

153. In one case, the parties eventually dismissed the appeal. Order at 1, Allan Block Corp. v. Cnty. Materials Corp., No. 0:05-cv-02879-JNE-JJG (D. Minn. Mar. 15, 2010), ECF No. 462. In the other case, the Federal Circuit affirmed the judgment. Judgment at 1, Avid Identification Sys., Inc. v. Phillips Elecs. N. Am. Corp., No. 2:04-cv-00183-TJW (E.D. Tex. Aug. 2, 2010), ECF No. 483 (on appeal, the case was docketed as Avid Identification Sys., Inc. v. Crystal Imp. Corp.).

154. See supra note 78. See Ohio Willow Wood Co. v. Thermo-Ply, Inc., 769 F. Supp. 2d 1065, 1066-71 (E.D. Tex. 2011), aff'd, 440 F. App'x 926, 926 (Fed. Cir. 2011).

155. U.S. Bancorp Mortg. Co. v. Bonner Mall P'ship, 513 U.S. 18, 28 (1994) (emphasis 
district court level, the data suggest that settlement-related vacatur does not appear to substantially affect the timing of settlements ${ }^{156}$ or case duration; ${ }^{157}$ rather, it appears to function primarily as a bargaining chip during settlement negotiations. ${ }^{158}$ Indeed, the average case duration in the vacatur dataset is comparable to the average duration in the general population of patent cases where the court had reached the merits of the patent liability issues. ${ }^{159}$ Furthermore, the average duration of the cases in the dataset where vacatur was granted is similar to that of the cases where vacatur was denied. ${ }^{160}$

In compiling the statistics for case duration, the time to termination was coded so that it reflected the actual duration of litigation between the parties-from the filing of the complaint to the termination of litigation in the district court through appeal, if any. As a result, the litigation termination date used to calculate the lawsuit duration for this empirical study may be different from the "termination date" listed in PACER, which may not always account for the time spent on postjudgment litigation or appeals. ${ }^{161}$ In coding the dataset, the date of litigation termination used in calculating the case duration was the date on which litigation ceased at both the trial and appellate levels between the parties that moved for vacatur, as determined as follows:

(1) The termination date is the date of the following items, whichever is later: (i) final district court order disposing of the merits and any collateral issues (such as fees and costs), (ii) consent judgment, (iii) stipulated dismissal (filed in district court), (iv) notice of satisfaction of judgment, or (v) Federal Circuit mandate.

(2) If there are multiple parties and the vacatur motion is brought in connection with a settlement between the patentee and a subset of the accused infringers, the termination date is the date on which litigation terminates between the settling parties and is determined using the criteria set forth in paragraph (1). ${ }^{162}$

(3) The time to termination does not include the litigation between the patentee and any third-party objector to the vacatur motion (such as an intervenor) that continues after the termination of litigation between the parties that moved for vacatur.

The table below summarizes the time to termination for the cases in the dataset:

in original).

156. See supra note 129 and accompanying text.

157. See infra Table 7.

158. See infra Table 7 and note 173.

159. See infra Table 7.

160. See infra Table 7 .

161. If the PACER termination date is used, the average case duration for the dataset decreases by 96 days. See infra note 163 .

162. This occurred in 3 out of 79 cases, where the patentee moved to vacate certain rulings associated with a specific party with whom the patentee planned to settle, while still actively litigating against the non-settling parties. The court granted vacatur in those 3 cases. 
Table 6: Time Between Filing of Complaint to Termination of Litigation in Dataset (in days)

\begin{tabular}{lcccc} 
& $\begin{array}{c}\text { All Cases } \\
\text { in Dataset } \\
N=79\end{array}$ & $\begin{array}{c}\text { Vacatur } \\
\text { Granted } \\
N=62\end{array}$ & $\begin{array}{c}\text { Vacatur } \\
\text { Denied } \\
N=15\end{array}$ & $\begin{array}{c}\text { Motion } \\
\text { Withdrawn } \\
N=2\end{array}$ \\
\hline \hline $\begin{array}{l}\text { Range } \\
\text { (Low/High) }\end{array}$ & $225 / 3737$ & $225 / 3737$ & $322 / 2275$ & $1399 / 2277$ \\
Average & 1272 & 1246 & 1304 & 1838 \\
Median & 1145 & 1136 & 1084 & 1838 \\
Std. Dev. & 661 & 687 & 547 & 621
\end{tabular}

The time to termination of the 79 cases in the vacatur dataset ranged from 225 days to 3737 days, with an average of 1272 days (median: 1145 days). ${ }^{163}$ Although there were too few cases where vacatur was denied $(N=15)$ to allow a comparison of the average durations for statistical significance, ${ }^{164}$ it is nevertheless notable that there is hardly any difference in the average (and median) termination times as a function of disposition: the granted cases have a slightly shorter average duration by 58 days (1246 days versus 1304 days), while their median duration is slightly longer than that of the denied cases by 52 days (1136 days versus 1084 days). The similarity in the average durations raised another question for investigation: if the average duration is not affected by the disposition of the vacatur motion, could it, instead, be affected by the fact that vacatur was requested? In other words, if the patentee filed a vacatur motion, would it mean that the patentee had taken a waitand-see approach that unduly prolonged litigation? As discussed below, the answer appears to be "no." 165

By way of comparison, the average duration of a patent case in the general population is approximately 15 months, or 450 days, ${ }^{166}$ which is a fraction of the average duration for the vacatur dataset (1272 days). However, this disparity

163. By way of comparison, if the PACER termination date is used, the average case duration is 1176 days, which is 96 days less than the average case duration (1272 days) calculated using the specific criteria formulated for the empirical study to account for appeals and post-judgment litigation. In calculating the PACER average, 3 cases were excluded because the grant of vacatur resulted in the termination of the litigation only as to a subset of the settling parties, such that the PACER termination date would not reflect the termination of the litigation specifically as to the settling parties.

164. See supra note 138 .

165. See infra notes 169-176 and accompanying text.

166. In a study of patent cases filed in 1995,1997 , and 2000 , the average number of days to termination was 418 days, 466 days, and 443 days, respectively. Kesan \& Ball, supra note 11, at 281-82. In a study of 2300 cases filed between January 2000 and March 2008 involving high-tech patents (that is, those covering hardware, software, and financial inventions), the average suit duration was less than 15 months. Colleen V. Chien, Of Trolls, Davids, Goliaths, and Kings: Narratives and Evidence in the Litigation of High-Tech Patents, 87 N.C. L. REv. 1571, 1593, 1595, 1605 tbl.6 (2009). 
reflects the substantial proportion of patent cases in the general population that are terminated shortly after filing or on procedural grounds without reaching the merits. ${ }^{167}$

Accordingly, for a more meaningful comparison of case-duration times, a "control" sample was compiled of 100 district court patent cases selected at random from a subset of the general population ${ }^{168}$ where the court reached the merits of the patent liability issues, as indicated by the issuance of, at a minimum, (i) a claim construction ruling, or (ii) a ruling (this includes minute orders and rulings denying summary judgment) addressing the merits of the parties' theories relating to infringement, validity, or enforceability. To minimize potential temporal bias, the control cases, like the vacatur dataset, were selected from the IPLC, and the termination dates of the control cases were restricted to the same time frame in which the vacatur motions were filed and decided (that is, January 1, 2006 to January 3 , 2011), with the termination dates determined using the same criteria described earlier in this section for the vacatur dataset. However, the control sample was designed to differ from the dataset in one key aspect: a settlement-related motion for vacatur (of any type of ruling) was not filed in any of the 100 control cases.

The table below compares the case duration of the control sample with the vacatur dataset.

167. Indeed, a substantial percentage of patent cases terminate with hardly any docket activity. See, e.g., Kesan \& Ball, supra note 11, at 285 tbl.12 (reporting that $43 \%$ of patent cases filed in $1995,46 \%$ in 1997 , and $43 \%$ in 2000 terminated with less than 20 documents filed). The first twenty documents in a patent case docket are typically the complaint, the answer, motions for extensions of time to file responsive pleadings, the summons, various administrative orders, corporate disclosure statements, notices of attorney appearance, pro hac vice motions, the scheduling order, and other prefatory filings. Only a minority of cases reach the summary judgment briefing stage. $I d$. at 287 (observing that motions for summary judgment were filed in $27 \%$ of patent cases filed in 1997 and in $24 \%$ of cases filed in 2000).

168. Cases were randomly selected using the IPLC until 100 cases were collected that fit the substance and timing criteria for the "control" sample. The following types of cases were excluded: (i) cases terminated based on default judgments or for want of prosecution, (ii) cases indefinitely stayed because of reexamination or bankruptcy, (iii) cases dismissed on procedural grounds (such as standing, jurisdiction, sufficiency of pleading), and (iv) cases where a settlement-related motion for vacatur (of any kind) was filed. To prevent doublecounting, transferred cases were counted only when the case associated with the transferee court was selected randomly, and consolidated cases were counted only if the lead case was selected randomly. Some consolidated cases (which include multi-jurisdictional litigation) can have numerous member cases, such that a single termination date for analytical purposes often cannot be suitably chosen; accordingly, consolidated cases involving more than five total member cases were excluded. Five was chosen as the limit for the size of the consolidated cases in the control sample because it corresponds to the size of the largest consolidated case in the vacatur dataset. 
Table 7: Case Duration: Control Sample and Vacatur Dataset (in days)

\begin{tabular}{l|c|cccc}
\cline { 2 - 5 } & $\begin{array}{c}\text { Control } \\
\text { Sample } \\
N=100\end{array}$ & $\begin{array}{c}\text { All Cases } \\
\text { in Dataset } \\
N=79\end{array}$ & $\begin{array}{c}\text { Vacatur } \\
\text { Granted } \\
N=62\end{array}$ & $\begin{array}{c}\text { Vacatur } \\
\text { Denied } \\
N=15\end{array}$ & $\begin{array}{c}\text { Motion } \\
\text { Withdrawn } \\
N=2\end{array}$ \\
\hline \hline $\begin{array}{l}\text { Range } \\
\text { (Low/High) }\end{array}$ & $132 / 3389$ & $225 / 3737$ & $225 / 3737$ & $322 / 2275$ & $1399 / 2277$ \\
Average & 1218 & 1272 & 1246 & 1304 & 1838 \\
Median & 980 & 1145 & 1136 & 1084 & 1838 \\
Std. Dev. & 692 & 661 & 687 & 547 & 621
\end{tabular}

The respective average durations of the control sample (1218 days) $)^{169}$ and that of the vacatur dataset (1272 days) differ by only 54 days; this difference is $n o t$ statistically significant. ${ }^{170}$ Notably, the percentage of cases in the control sample that involved an appeal ${ }^{171}$ (45\%; 45 out of 100 cases) was higher than that of the vacatur dataset (34.2\%; 27 out of 79 cases). ${ }^{172}$ This result was expected because the parties are essentially treating vacatur as an alternative to appeal.

The similarity in the average case duration between the control sample and the vacatur dataset suggests that at least at the district court level, the patentee's desire for settlement-related vacatur does not appear to be the primary motivating force behind when the parties begin settlement discussions. Instead, it is more likely that vacatur motions are filed as a result of their use as bargaining chips ${ }^{173}$ during settlement negotiations. That is, for the cases in the dataset, settlement-related vacatur appears to influence the price of settlements more than their timing.

169. For this sample of 100 control cases, the $95 \%$ confidence interval for the average duration is 1081 to 1355 days, and the margin of error, which is one-half of the confidence interval, is \pm 137 days. If the PACER termination date is used, the average case duration for the control cases would be 1055 days, which is 163 days less than the average case duration (1218 days) calculated using the specific criteria formulated for the empirical study to account for appeals and post-judgment litigation.

170. Using a two-sample t-test assuming unequal variances and unpaired values, the twotailed p-value is 0.5929 .

171. A case was coded as "appealed" if the parties filed a notice of appeal at any point in the litigation. Writs of mandamus and notices of appeal filed by non-parties (such as potential intervenors) were not counted.

172. This difference is not statistically significant. Using Fisher's exact test, the twotailed p-value is 0.168. See supra note 132 .

173. See, e.g., Judith Resnik, Whose Judgment? Vacating Judgments, Preferences for Settlement, and the Role of Adjudication at the Close of the Twentieth Century, 41 UCLA L. REV. 1471, 1491 (1994) [hereinafter Resnik, Whose Judgment?] ("When the judicial opinion becomes available as a 'bargaining chip,' the purchasing power of litigants grows." (footnote omitted)); see also Fisch, supra note 2, at 641 ("[A] prevailing litigant may be the beneficiary of the bargaining advantage afforded . . . by the additional costs the judgment imposes on the other side. A well-informed litigant should be able to negotiate a higher postjudgment settlement if he agrees to vacatur as a condition of settlement."). 
More generally, the type of "roll the dice" litigation strategy criticized in Bancorp ${ }^{174}$ cannot be successfully executed unless the patentee can be certainprior to the issuance of a potentially adverse decision - that the court will actually grant vacatur upon request. ${ }^{175}$ Accordingly, in view of the denial rate of $19 \%$ (15 out of 79 cases) in the dataset, it is unlikely that patentees can confidently engage in a "roll the dice" litigation strategy based on the prospect of having the court vacate any inconvenient rulings. Furthermore, because a critical trait of a successful motion for vacatur at the district court level is the absence of opposition, a patentee may not know whether moving for vacatur is a feasible option until the case is at the settlement stage, where it may be suggested for the first time by a mediator ${ }^{176}$ and the opposing party does not object.

However, with the increasing sophistication of legal informatics and granular docket information available to litigants (such as the IPLC and Docket Navigator), ${ }^{177}$ it may be possible in the near future for patentees to systematically analyze and accurately discern the case conditions (such as court/judge, accused infringer, opposing counsel) under which motions for settlement-related vacatur have a high likelihood of being granted. Repeat litigants could use such information to steer cases to certain courts or judges who are known to reliably grant vacatur, which could render "rolling the dice" a viable litigation strategy in some cases. Accordingly, from the standpoint of judicial economy, it may be beneficial for judges to deny settlement-related vacatur so as to avoid developing a reputation for granting them.

\section{Vacatur as a Condition of Settlement}

One of the concerns a court may have with a motion for vacatur is whether settlement may not occur, or whether a recent settlement may break down (prior to the deadline for reopening a terminated case) ${ }^{178}$ if vacatur were denied. In a majority of cases $(67.1 \%$; 53 out of 79$)$, the motions did not expressly state that settlement was contingent on the grant of vacatur. However, in a sizeable minority of cases $(22.8 \%$; 18 out of 79$)$ the motions did include an express representation of

174. See supra note 155 and accompanying text.

175. See supra note 155 and accompanying text; see also Fisch, supra note 2, at 596 ("[I]f a litigant is certain that the court will subsequently vacate an adverse judgment, the availability of vacatur makes going to trial cost-free, apart from litigation costs." (footnotes omitted)). Thus, it is only under a regime that grants settlement-related vacatur motions nearly automatically that a party's desire to "roll the dice" may be the primary influence on case duration.

176. See, e.g., Mark D. DeBofsky, Mediating in the Appellate Court, 34 LitiG. 47, 51 (2008) ("[A]s long as the lower court is willing to go along, many mediators use the possibility of vacatur as a settlement tool." (emphasis in original)).

177. See supra notes 8-9.

178. In some cases, a district court will provide a window during which settling parties may reopen a case after termination in the event the settlement fails. See, e.g., Cupid Founds., Inc. v. Jupi Corp., No. 2:07-cv-05506-JLL-CCC (D.N.J. Apr. 5, 2010), ECF No. 83 (providing sixty-day window). In $6.3 \%$ of the cases in the dataset (5 out of 79), the vacatur motion was filed after the date on which litigation terminated. 
conditionality. The $67.1 \%$ and $22.8 \%$ figures are lower bounds because the motions in the remaining $10.1 \%$ of the cases ( 8 out of 79) were not accessible because they were filed under seal or no formal motion was filed. Table 8 tallies the disposition of the vacatur motions as a function of any statements of conditionality. ${ }^{179}$

\section{Table 8: Conditionality Statements and Disposition of Vacatur Motions (\# of cases)}

\begin{tabular}{lccc} 
Disposition & $\begin{array}{c}\text { No statement in } \\
\text { Motion conditioning } \\
\text { settlement on grant } \\
N=53(\% \text { of } 53)\end{array}$ & $\begin{array}{c}\text { Motion stated that } \\
\text { settlement was } \\
\text { conditioned on grant } \\
N=18(\% \text { of } 18)\end{array}$ & $\begin{array}{c}\text { Motion Inaccessible } \\
\text { (sealed or not filed) } \\
N=8 \text { (\% of } 8)\end{array}$ \\
\hline \hline Granted & $37(69.8 \%)$ & $18(100 \%)$ & $7(87.5 \%)$ \\
$\begin{array}{l}\text { Denied } \\
\text { Motion } \\
\text { Withdrawn }\end{array}$ & $15(28.3 \%)$ & 0 & 0 \\
\end{tabular}

In the dataset, courts denied vacatur only when the motion did not contain a statement that the settlement was conditioned on its grant. In contrast, when the motion contained a statement of conditionality, it was granted in every case. The difference in the grant rate as a function of whether the vacatur motion contained an express statement of conditionality $(69.8 \%$, not conditioned, versus $100 \%$, conditioned) is highly statistically significant. ${ }^{180}$

Based on these results, it may be possible for a patentee to effectively guarantee vacatur by representing to the court that the settlement is conditioned on its grant. That such contingencies are not more common, as illustrated by the majority of the cases in the dataset (67.1\%; 53 out of 79) having motions that do not contain a statement of conditionality, suggests that accused infringers are often unwilling to condition settlement on vacatur, and instead prefer to limit their support of any vacatur motion to non-opposition. From the standpoint of judicial economy, however, if district courts were to automatically grant vacatur so long as it was an express condition of settlement, it may have the perverse effect of rewarding patentees who delay settlement until the litigation progresses to a point where the patentee has essentially worn down the accused infringer, who might then agree to

179. The conditionality variable was coded "yes" only if the motion expressly stated that the grant of vacatur was a condition of settlement. The coding was based on the contents of the motion, and any briefs or memoranda filed in support, but not any attached exhibits, such as settlement agreements, which were usually filed under seal. It was assumed that if the parties did intend for the settlement to be contingent on the grant of vacatur, it would be a material fact that would have been highlighted in the motion itself.

180. Counting only the 71 "accessible" motions, the two-tailed p-value using Fisher's exact test is 0.007 . If all 8 "inaccessible" motions contained statements of conditionality, then Fisher's exact test would return a two-tailed p-value of 0.008 . Conversely, if all 8 "inaccessible" motions did not contain any statements of conditionality, then Fisher's exact test would return a two-tailed p-value of 0.009 . 
the patentee's demand to condition the settlement on the grant of vacatur. As discussed in the previous section, a "roll the dice" litigation strategy that delays settlement could result if there is a condition under which vacatur is effectively guaranteed. ${ }^{181}$ By denying vacatur even when the settlement agreement is contingent on it, district courts may guard themselves against such tactics. Furthermore, if the denial of vacatur prompts the parties to actively litigate through appeal, allowing the litigation to run its course may ultimately provide greater benefits for judicial economy and the public interest because it will lead to a final disposition that will lend a degree of certainty on issues affecting patent scope, validity, or enforceability. Greater certainty on patent liability issues may result in a net decrease in litigation, whereas continued uncertainty may have the opposite effect. $^{182}$

If the vacatur motion does not contain an express representation that the settlement is conditioned on vacatur, the data suggest that its denial is unlikely to jeopardize settlement: in each of the 15 cases where the court denied vacatur, the settlement remained intact. However, the existence of a settlement may not always end litigation. Although the settlement itself may not be contingent on vacatur, denial may nevertheless result in continued litigation by the patentee-unopposed. This happened in 2 out of the 15 cases where vacatur was denied: litigation continued whereby the patentee filed an unopposed appeal from the judgment (and the subsidiary rulings) that it had unsuccessfully targeted for vacatur. Notably, neither of these appeals resulted in a reversal or a remand: in one of the cases, the parties eventually dismissed the appeal, ${ }^{183}$ and in the other case, the Federal Circuit affirmed the judgment. ${ }^{184}$ Such unopposed appeals following the denial of vacatur, are, in effect, an attempt by the patentee to have it both ways-a settlement as well as an uncontested appeal. This practice could be readily curtailed by the Federal Circuit through the rigorous application of the mootness doctrine to appeals resulting from the denial of settlement-related vacatur by dismissing the appeal if the accused infringer had settled with the patentee and chosen not to oppose the appeal on the merits. ${ }^{185}$

181. See supra Part IV.C.

182. See, e.g., George L. Priest \& Benjamin Klein, The Selection of Disputes for Litigation, 13 J. LEGAL STUD. 1, 17 (1984) ("In litigation, as in gambling, agreement over the outcome leads parties to drop out. . . Where either the plaintiff or defendant has a 'powerful' case, settlement is more likely because the parties are less likely to disagree about the outcome.").

183. Order at 1, Allan Block Corp. v. Cnty. Materials Corp., No. 0:05-cv-02879-JNE-JJG (D. Minn. Mar. 15, 2010), ECF No. 462.

184. Judgment at 1, Avid Identification Sys., Inc. v. Phillips Elecs. N. Am. Corp., No. 2:04-cv-00183-TJW (E.D. Tex. Aug. 2, 2010), ECF No. 483 (on appeal, the case was docketed as "Avid Identification Sys., Inc. v. Crystal Imp. Corp.").

185. See, e.g., Aqua Marine Supply v. AIM Machining, Inc., 247 F.3d 1216, 1220 (Fed. Cir. 2001) ("While in some circumstances the opposing party's lack of interest will not bar adjudication on the merits, the outcome is different when the appellant is responsible for the opposing party's lack of continued interest, for example, as here by a settlement." (internal citation omitted)). But see Avid Identification Sys., Inc. v. Crystal Imp. Corp., 603 F.3d 967, 971-72 (Fed. Cir. 2010) ("A live controversy still exists because [the accused infringer] remained free under the settlement agreement to oppose this appeal on the merits. That it 


\section{E. Patent Characteristics, Vacatur, and Relitigation}

\section{Litigation History}

If a patent ${ }^{186}$ has a history of being litigated, would a district court be more or less likely to grant vacatur of an adverse ruling affecting that patent? Surprisingly, the vacatur grant rate in cases involving a patent with a history of litigation is similar to those cases where the patent has no such history, ${ }^{187}$ even though the former have a much higher likelihood of being involved in future litigation. ${ }^{188}$

To analyze settlement-related vacatur in the context of a patent's litigation history, the author gathered the relevant data as follows: for each case in the dataset, each docket item targeted in the vacatur motion was reviewed to determine which patents would be affected by (that is, benefit from) the grant of vacatur, and those patent numbers were entered into the IPLC search field to determine whether those patents were asserted in other cases. In tallying the number of suits associated with the patents ${ }^{189}$ for a given case in the dataset, ${ }^{190}$ transferred cases were counted once. If the same patent was asserted in multiple cases that were later consolidated, the individual member cases were counted separately. False marking cases were not counted.

In over half of the cases in the dataset (54.4\%; 43 out of 79 cases), the patentee sought vacatur of rulings affecting patents with a history of litigation at the time the vacatur motion was filed, which confirms the analysis in the academic literature that repeat litigants are more likely to seek vacatur. ${ }^{191}$ The 43 cases (out of 79) in

chose not to submit a brief does not deprive this court of jurisdiction over the issues on appeal." (internal citation omitted)).

186. Throughout this Article, all references to "patents" associated with a case in the dataset will refer to those patents that would be affected by (that is, benefit from) the grant of vacatur, which may be a subset of the patents in a given case.

187. See infra Table 9.

188. See infra Tables $11 \mathrm{a} \& 11 \mathrm{~b}$.

189. While it would have been ideal to compile the litigation history on a claim-by-claim basis rather than on the patent as a whole, finding reliable claim information is difficult because the identity of the asserted claims is usually not available in a public filing until the parties prepare substantive briefs for claim construction or summary judgment, which will not exist for cases that were filed recently or that terminated prior to the claim construction briefing stage. In contrast, compiling the litigation history at the patent level can be performed more reliably because the asserted patents are listed in the complaint or in the answer (as counterclaims). Also, any lack of precision that may result from focusing on the patent, as opposed to each individual claim, is mitigated by the fact that the rulings of interest that are targeted for vacatur are generally those that may have collateral estoppel effect, which may apply to unadjudicated claims so long as those claims present issues identical to the ones that were adjudicated. See Bourns, Inc. v. United States, 537 F.2d 486 (Ct. Cl. 1976). Bourns, as a decision issued by the Court of Claims, a predecessor court of the Federal Circuit, is treated as Federal Circuit precedent. See South Corp. v. United States, 690 F.2d 1368, 1369 (Fed. Cir. 1982) (en banc).

190. If a case in the dataset has multiple patents that would benefit from the grant of vacatur, the litigation histories of those patents were aggregated into a single set of statistics associated with that specific case.

191. See, e.g., Resnik, Whose Judgment?, supra note 173, at 1488 ("The very existence 
the dataset that involve patents with a history of litigation may be classified into three subtypes: (1) cases having patents that were involved in prior litigation, ${ }^{192}$ (2) cases having patents that are being asserted in concurrent litigation, ${ }^{193}$ and (3) cases having patents that were involved in prior litigation and are also being asserted in concurrent litigation. The distribution of cases having patents falling under one of these three subtypes is shown in the figure below.

\section{Figure 1: Distribution of Cases in Dataset Involving Patents Having One of Three Possible Types of Litigation History (\# of Cases and \% of Dataset (out of 79 cases))}

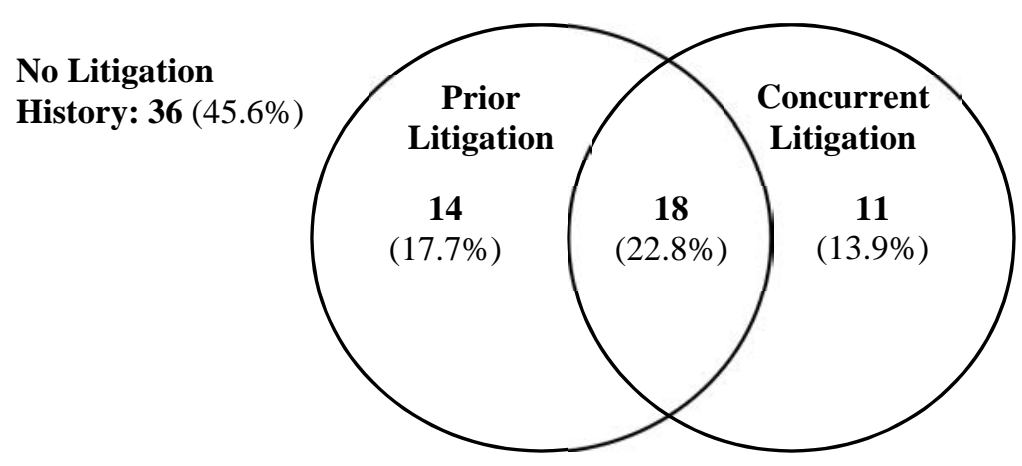

In addition to eliminating any potential collateral estoppel effect of an adverse ruling, a patentee may seek vacatur for a variety of reasons unrelated to litigation, including, (i) protecting its position in extrajudicial proceedings (for example, arbitration or proceedings in the Patent Office), (ii) initiating a licensing campaign or maintaining the flow of payments from existing licensees, ${ }^{194}$ and (iii) using the

of a reported opinion might also be seen as an encumbrance, influencing behavior. One can therefore assume that not all litigants care equally about the existence of recorded judicial opinions and that repeat players are more likely than one-shotters to be proponents of vacatur.").

192. In coding the dataset, "prior" litigation was deemed to be any previous litigation involving a patent that would benefit from the grant of vacatur that terminated prior to the date of the vacatur motion.

193. In coding the dataset, "concurrent" litigation was deemed to be parallel litigation involving a patent that would benefit from the grant of vacatur that was pending at the time the vacatur motion was filed. Member cases in a consolidated action were counted as "concurrent" litigation if, at the time they were initially filed (as separate suits), the same patent was being asserted. The total number of cases with "concurrent" litigation includes one case that had a concurrently-filed patent suit against the United States government in the Court of Federal Claims, which was mentioned in the vacatur motion in that case. (When the vacatur dataset was being compiled, the IPLC did not contain patent cases from the Court of Federal Claims.) If a suit was filed after the date of the vacatur motion but before the court ruled on it, such suits were coded as "concurrent."

194. An unenforced, invalid patent helps to "maintain an illegitimate monopoly" for the patent holder without having to bring suit. Christopher R. Leslie, The Anticompetitive Effects of Unenforced Invalid Patents, 91 MinN. L. REV. 101, 103 (2006). 
patent as a "scarecrow," to borrow a term from Learned Hand, ${ }^{195}$ in the supply chain to dissuade potential and existing customers and suppliers from using or supplying parts for competing products that allegedly infringe. ${ }^{196}$ As a result, the impact of a patentee securing vacatur of an adverse decision may have substantial effects on third parties beyond any potential effects on future district court litigation. If a patent has a history of litigation, the non-litigation effects listed above are likely to be greater than in cases where the patent has not been previously asserted or if the patentee is not known to be litigious. Yet, the data suggest that litigation history does not appear to be a substantial consideration when courts decide vacatur motions, as shown below.

\section{Table 9: Disposition of Vacatur Motion Based on Litigation History of Patents (\# of Cases)}

\begin{tabular}{lcc} 
Disposition & $\begin{array}{c}\text { No Litigation } \\
\text { History at Time of } \\
\text { Vacatur Motion } \\
N=36(\% \text { of } 36)\end{array}$ & $\begin{array}{c}\text { Prior/Concurrent } \\
\text { Litigation at Time of } \\
\text { Vacatur Motion } \\
N=43(\% \text { of } 43)\end{array}$ \\
\hline \hline Vacatur Granted & $30(83.3 \%)$ & $32(74.4 \%)$ \\
Vacatur Denied & $5(13.9 \%)$ & $10(23.3 \%)$ \\
Motion Withdrawn & $1(2.8 \%)$ & $1(2.3 \%)$
\end{tabular}

There is no statistically significant difference in vacatur grant rates $(83.3 \%$ versus $74.4 \%$ ) between cases involving patents having no history of litigation compared to those that do. ${ }^{197}$ The similarity in grant rates further illustrates the heavy bias of the courts toward facilitating settlement, despite the greater likelihood of potential ripple effects in both litigation and non-litigation contexts posed by patents with a history of litigation.

Indeed, even when the same patent was being litigated in parallel before a different judge at the time the vacatur motion was filed, vacatur was still granted in an overwhelming majority of cases, as shown in the table below.

195. Bresnick v. U.S. Vitamin Corp., 139 F.2d 239, 242 (2d Cir. 1943) (Hand, J.) ("We have disposed of the patent as a whole because it has seemed to us proper that it should not remain in the art as a scarecrow.").

196. See, e.g., Leslie, supra note 194, at 125-26.

197. Using Fisher's exact test, the two-tailed p-value is 0.415 . 


\section{Table 10: Existence of Concurrent Litigation Handled by Other Judges and Disposition of Vacatur Motion (\# of Cases)}

\begin{tabular}{lcc} 
Disposition & $\begin{array}{c}\text { Patents NOT Involved in } \\
\text { Concurrent Litigation } \\
\text { Before Other Judges } \\
N=61(\% \text { of } 61)\end{array}$ & $\begin{array}{c}\text { Patents Involved in } \\
\text { Concurrent Litigation } \\
\text { Before Other Judges } \\
N=18(\% \text { of } 18)\end{array}$ \\
\hline \hline Vacatur Granted & $49(80.3 \%)$ & $13(72.2 \%)$ \\
Vacatur Denied & $10(16.4 \%)$ & $5(27.8 \%)$ \\
Motion Withdrawn & $2(3.3 \%)$ & 0
\end{tabular}

There is no statistically significant difference in the rate of granting vacatur (80.3\% versus $72.2 \%$ ) as a function of whether the same patent is being concurrently litigated before a different judge. ${ }^{198}$ The marginal difference in grant rates further supports the inference that district courts are effectively prioritizing near-term docket relief above overall judicial economy and comity. As discussed previously, vacating an otherwise non-defective ruling for no reason other than to facilitate settlement can be highly disruptive to other courts, especially when they must, in turn, vacate their own decisions that had relied on according collateral estoppel effect to that earlier-now vacated-ruling. ${ }^{199}$ The goals of judicial economy and comity may be better served if otherwise non-defective rulings are never vacated if concurrent litigation exists in other courts.

Turning now to relitigation, the data reveal that a disproportionate number of additional suits filed after the ruling on the vacatur motion involve patents with a history of litigation. ${ }^{200}$

As of January 9, 2012, the patents implicated by the vacatur motions filed in 17 out of 79 cases in the dataset $(21.5 \%)$ were involved in a total of 60 additional suits filed after the court issued a ruling on the vacatur motion. The data on subsequent suits will necessarily be underreported and incomplete because a patentee may decide to wait years before filing another suit, which may occur at any time up to six years after a patent's expiration date. ${ }^{201}$

As summarized in the tables below, of the 60 additional cases that were filed after the courts ruled on the vacatur motions, 54 cases (90\%) involved patents that had a history of litigation at the time the vacatur motion was filed. The following tables summarize the numerical relationships in the dataset relating to the grant/denial of vacatur, whether the case involves a patent with a history of litigation, and the aggregate number of subsequent cases filed after the ruling on the vacatur motion. Because additional suits were filed even when vacatur was denied, separate tables were prepared for the granted and denied cases. ${ }^{202}$

198. Using Fisher's exact test, the two-tailed p-value is 0.519.

199. See FED. R. CIV. P. 60(b)(5); supra note 140 and accompanying text.

200. See infra Tables $11 \mathrm{a}$ and $11 \mathrm{~b}$.

201. See 35 U.S.C. $\S 286$ (2006).

202. As of January 9, 2012, none of the patents associated with the 2 cases where the 
Table 11a: Relationship Between Litigation History and Subsequent Litigation After Vacatur GRANTED

\begin{tabular}{lcccc} 
Vacatur & $\begin{array}{c}\text { Cases Whose } \\
\text { Patents Were Not } \\
\text { Subsequently } \\
\text { Pitigated } \\
N=47\end{array}$ & $\begin{array}{c}\text { Cases Whose } \\
\text { Patents Were } \\
\text { Subsequently } \\
\text { Litigated } \\
N=15\end{array}$ & $\begin{array}{c}\text { New Cases } \\
\text { Filed After } \\
\text { Vacatur } \\
\text { Granted } \\
N=56\end{array}$ \\
\hline \hline $\begin{array}{l}\text { Granted } \\
N=62\end{array}$ & $\begin{array}{c}\text { 19 out of } 32 \\
(59.4 \%)\end{array}$ & $\begin{array}{c}13 \text { out of } 32 \\
(40.6 \%)\end{array}$ & 50 \\
$\begin{array}{l}\text { Prior/Concurrent } \\
\text { Litigation at }\end{array}$ & 32 & & & \\
$\begin{array}{l}\text { Time of Motion } \\
\text { No Litigation } \\
\text { History at Time } \\
\text { of Motion }\end{array}$ & 30 & $\begin{array}{c}28 \text { out of } 30 \\
(93.3 \%)\end{array}$ & $\begin{array}{c}2 \text { out of } 30 \\
(6.7 \%)\end{array}$ & 6
\end{tabular}

\section{Table 11b: Relationship Between Litigation History and Subsequent} Litigation After Vacatur DENIED

\begin{tabular}{|c|c|c|c|c|}
\hline $\begin{array}{l}\text { Cases Involving } \\
\text { Patents with- }\end{array}$ & $\begin{array}{c}\text { Vacatur } \\
\text { Denied } \\
N=15\end{array}$ & $\begin{array}{c}\text { Cases Whose } \\
\text { Patents Were Not } \\
\text { Subsequently } \\
\text { Litigated } \\
N=13\end{array}$ & $\begin{array}{l}\text { Cases Whose } \\
\text { Patents Were } \\
\text { Subsequently } \\
\text { Litigated } \\
\quad N=2\end{array}$ & $\begin{array}{c}\text { New Cases } \\
\text { Filed After } \\
\text { Vacatur } \\
\text { Denied } \\
N=4\end{array}$ \\
\hline $\begin{array}{l}\text { Prior/Concurrent } \\
\text { Litigation at } \\
\text { Time of Motion }\end{array}$ & 10 & $\begin{array}{c}8 \text { out of } 10 \\
(80 \%)\end{array}$ & $\begin{array}{c}2 \text { out of } 10 \\
(20 \%)\end{array}$ & 4 \\
\hline $\begin{array}{l}\text { No Litigation } \\
\text { History at Time } \\
\text { of Motion }\end{array}$ & 5 & $\begin{array}{c}5 \text { out of } 5 \\
(100 \%)\end{array}$ & $\begin{array}{c}0 \text { out of } 5 \\
(0 \%)\end{array}$ & 0 \\
\hline
\end{tabular}

Comparing Tables $11 \mathrm{a}$ and $11 \mathrm{~b}$ at a high level, when vacatur was granted in 62 cases, the patents associated with 15 of those cases (24.2\%; 15 out of 62 ) were asserted in 56 new suits (3.7 subsequent suits per case), whereas when vacatur was denied in 15 cases, the patents associated with 2 of those cases (13.3\%; 2 out of 15) were asserted in only 4 new suits ( 2 subsequent suits per case). These statistics suggest that (1) the patents associated with only a fraction of the cases in which vacatur is requested may be involved in subsequent suits, (2) when those patents are relitigated, multiple assertions are likely; and (3) the denial of vacatur does not necessarily prevent subsequent suits, but it may dampen their frequency.

vacatur motion was withdrawn were involved in subsequent litigation. 
Looking more closely at Table $11 \mathrm{a}$, the number of cases where vacatur was granted is substantially similar between the cases involving patents with a history of litigation compared to those cases with patents that were being asserted for the first time (32 versus 30, out of 62 cases). However, the difference in relitigation rates of the patents associated with these two groups of cases is striking $(40.6 \%$ versus $6.7 \%$ ). This difference is highly statistically significant. ${ }^{203}$ In addition, looking at Table $11 \mathrm{~b}$, only the patents having a history of litigation were relitigated when vacatur was denied.

Because more than half of the cases in the dataset involve patents with a history of litigation - and the patents associated with only a fraction of those cases are relitigated - we will also need to look at the characteristics of the patentee and the technology in order to further refine the criteria for spotting cases with patents that have a high likelihood of relitigation. This will be discussed in the remainder of Part IV.E.

\section{Patentee Type}

If a certain type of patentee has a reputation for litigiousness, would this prompt courts to deny vacatur for that type of patentee more often than others? According to the dataset, the answer is, surprisingly, "no." To analyze the possible effect of patentee type on the grant of vacatur and relitigation, the patentees in the vacatur dataset were classified into three groups-practicing company, patent assertion entity (PAE), and individual—as follows: ${ }^{204}$

(1) Practicing Company: A patentee was classified as a "practicing company" if it was primarily engaged in the production or sale of goods and services. In addition, companies whose primary focus is not production but the active development of new technologies through substantial research and development (R\&D) activity were also classified as "practicing companies."

(2) Patent Assertion Entity (PAE): A patentee was classified as a "patent assertion entity" if it had no presence on the Internet except in connection with patent litigation-related webpages or is a company (which may be a subsidiary of a practicing company) whose primary focus is the litigation or licensing (that is, monetization) of patents.

(3) Individuals: If an individual sued in his or her own name, then the patentee was classified as an "individual."

203. Using Fisher's exact test, the two-tailed p-value is 0.002 .

204. The three classifications are largely modeled after those defined in Colleen V. Chien, Predicting Patent Litigation, 90 Tex. L. Rev. 283, 314 n.209 (2011), with certain modifications for purposes of the vacatur dataset. The patentee classification was based on the first-named plaintiff (or defendant in a declaratory judgment action) listed in the caption of the vacatur motion or the associated order (if the motion itself was unavailable). Foreign entities were classified using the same criteria as domestic entities. None of the first-named patentees in the dataset were universities. 
The table below summarizes the number of patentee types and the associated vacatur grant rate and relitigation statistics:

Table 12: Vacatur Grant and Relitigation by Patentee Type

\begin{tabular}{|c|c|c|c|c|}
\hline Patentee Type & $\begin{array}{c}\text { Cases in } \\
\text { Dataset } \\
N=79 \\
(\% \text { of } 79)\end{array}$ & $\begin{array}{c}\text { Vacatur } \\
\text { Granted } \\
N=62\end{array}$ & $\begin{array}{c}\text { Cases Whose } \\
\text { Patents Were } \\
\text { Subsequently } \\
\text { Litigated } \\
\quad N=17\end{array}$ & $\begin{array}{c}\text { New Cases } \\
\text { Filed After } \\
\text { Vacatur Ruling } \\
N=60 \\
(\% \text { of } 60)\end{array}$ \\
\hline $\begin{array}{l}\text { Practicing } \\
\text { Company }\end{array}$ & $\begin{array}{c}59 \\
(74.7 \%)\end{array}$ & $\begin{array}{c}45 \text { out of } 59 \\
(76.3 \%)\end{array}$ & $\begin{array}{c}9 \text { out of } 59 \\
(15.3 \%)\end{array}$ & $\begin{array}{c}41 \\
(68.3 \%)\end{array}$ \\
\hline $\begin{array}{l}\text { Patent Assertion } \\
\text { Entity (PAE) }\end{array}$ & $\begin{array}{c}15 \\
(19 \%)\end{array}$ & $\begin{array}{c}14 \text { out of } 15 \\
(93.3 \%)\end{array}$ & $\begin{array}{c}8 \text { out of } 15 \\
(53.3 \%)\end{array}$ & $\begin{array}{c}19 \\
(31.7 \%)\end{array}$ \\
\hline Individual & $\begin{array}{c}5 \\
(6.3 \%)\end{array}$ & $\begin{array}{c}3 \text { out of } 5 \\
(60 \%)\end{array}$ & $\begin{array}{c}0 \text { out of } 5 \\
(0 \%)\end{array}$ & 0 \\
\hline
\end{tabular}

A substantial majority of the patentees who requested vacatur were practicing companies (74.7\%), followed by PAEs (19\%) and individuals (6.3\%). Notably, the vacatur grant rate is the highest for PAEs (93.3\%; 14 out of 15 cases), followed by practicing companies $(76.3 \%$; 45 out of 59 cases), and individuals ( $60 \% ; 3$ out of 5 cases). ${ }^{205}$ That the patents ${ }^{206}$ in more than half of the PAE cases in the dataset $(53.3 \%$; 8 out of 15 cases) were involved in subsequent litigation is unsurprising given the PAE business model of asserting the same patents against numerous parties. $^{207}$ The difference in the relitigation rate of patents from PAE cases compared to that of practicing companies (53.3\% versus $15.3 \%)$ is highly statistically significant. ${ }^{208}$ Indeed, although PAE cases constituted only $19 \%$ of the dataset (15 out of 79 cases), the patents from those cases were involved in $31.7 \%$ of the new suits (19 out of 60 cases) filed after the ruling on the vacatur motion, as shown below.

205. The difference in grant rates for PAE cases versus non-PAE cases, while substantial, is not statistically significant: using Fisher's exact test, the two-tailed p-value is 0.17 .

206. That is, patents that would have benefitted from the grant of vacatur.

207. See, e.g., John R. Allison, Mark A. Lemley \& Joshua Walker, Extreme Value or Trolls on Top? The Characteristics of the Most-Litigated Patents, 158 U. PA. L. REV. 1, 32 (2009) [hereinafter Allison et al., Extreme Value] (observing that PAEs "account for only about $16 \%$ of the once-litigated patents, [but] represent over $80 \%$ of the suits filed involving the most-litigated patents and own more than $50 \%$ of the most-litigated patents themselves"). 208. Using Fisher's exact test, the two-tailed p-value is 0.004. 
Figure 2: Patentee Type in Dataset and New Cases Filed After Ruling on Vacatur Motion (Relative Percentages)

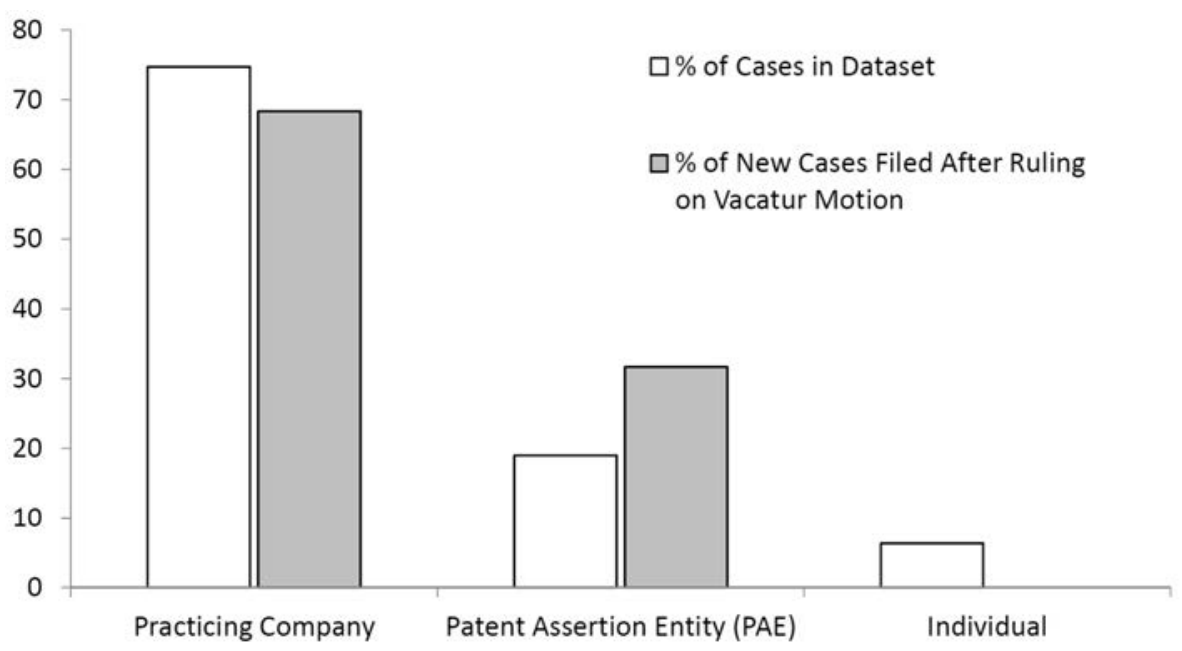

That courts granted vacatur in PAE cases at a rate higher than in any other type of case in the dataset appears counterintuitive because the availability of collateral estoppel will have the greatest utility against PAE patents-which have a high likelihood of relitigation - and vacatur was an express condition of settlement in, at most, 4 out of the $15 \mathrm{PAE}$ cases in the dataset. ${ }^{209}$ One possible explanation for the willingness of courts to grant vacatur in PAE cases may be grounded in the perception that PAEs, after an adverse ruling on an issue of patent liability, may be more willing to continue litigation through appeal than other types of patentees. For example, a PAE does not produce any products, such that, unlike a practicing company, it will not be subject to counterclaims for infringement that can be used as leverage for settlement. In addition, PAEs, whose primary sources of revenue are royalties and settlement payments, are often represented on a contingency basis, such that they have a strong incentive to appeal any adverse ruling that might foreclose the recovery of damages or settlement payments in other suits.

Granting settlement-related vacatur when the patentee is known to be litigious might provide a court with near-term docket relief; however, as discussed further in Part IV.E.4, long-term judicial economy and the public interest may be better served if vacatur were denied in such cases.

\section{Technology Area}

To evaluate whether any relationships might exist between the type of technology, the grant of settlement-related vacatur, and relitigation, each case in the

209. In the 15 PAE cases, the vacatur motions in 2 cases contained an express statement of conditionality, and in the 2 other cases, a formal motion was not filed such that conditionality could not be determined. 
dataset was assigned to one of six technical categories ${ }^{210}$ based on the subject matter of the patents that would benefit from the grant of vacatur. The six categories were defined as follows:

(1) Pharmaceutical: Chemicals for treating medical conditions, and methods for developing, manufacturing, using, or administering the same.

(2) Semiconductor: Semiconductor circuits/devices, and equipment and methods for designing, testing, and fabricating the same.

(3) Computer, Electronics, and Software (CES): Hybrid category covering inventions where underlying technology that is primary focus of claim scope is directed to computers, electronics, software, or combination thereof.

(4) Medical: Inventions related to treating or diagnosing medical conditions, as well as inventions for conducting medical research. This category excludes pharmaceuticals.

(5) Mechanical: Inventions relating primarily to manufacturing, configuring, or using mechanical devices or parts, or key aspect of the invention involves use of mechanical devices or parts.

(6) Other: Inventions that do not fall into categories listed above.

The table below tallies the number of cases in each technology area and summarizes their dispositions and relitigation statistics.

210. The categories were defined specifically for this Article in light of the inadequacies of the U.S. Patent and Trademark Office's classification system, as noted by other scholars. See, e.g., John R. Allison \& Mark A. Lemley, Who's Patenting What? An Empirical Exploration of Patent Prosecution, 53 VAND. L. REV. 2099, 2114 (2000) (“[W]e did not find [the PTO classification system] particularly reliable. . . [W] came upon numerous instances of what appear to us to be wrong or arbitrary classification decisions. . . [T] PTO system groups together technologies that may have very different characteristics."). 
Table 13: Vacatur Grant and Relitigation by Technology Area

\begin{tabular}{|c|c|c|c|c|}
\hline Technology Area & $\begin{array}{c}\text { Cases in } \\
\text { Dataset } \\
N=79 \\
(\% \text { of } 79)\end{array}$ & $\begin{array}{c}\text { Vacatur } \\
\text { Granted } \\
N=62\end{array}$ & $\begin{array}{c}\text { Cases Whose } \\
\text { Patents Were } \\
\text { Subsequently } \\
\text { Litigated } \\
\quad N=17\end{array}$ & $\begin{array}{c}\text { New Cases } \\
\text { Filed After } \\
\text { Vacatur } \\
\text { Ruling } \\
N=60 \\
(\% \text { of } 60) \\
\end{array}$ \\
\hline Pharmaceutical & $\begin{array}{c}5 \\
(6.3 \%)\end{array}$ & $\begin{array}{c}3 \text { out of } 5 \\
(60 \%)\end{array}$ & $\begin{array}{c}4 \text { out of } 5 \\
(80 \%)\end{array}$ & $\begin{array}{c}19 \\
(31.7 \%)\end{array}$ \\
\hline Semiconductor & $\begin{array}{c}5 \\
(6.3 \%)\end{array}$ & $\begin{array}{l}3 \text { out of } 5 \\
(60 \%)\end{array}$ & $\begin{array}{c}2 \text { out of } 5 \\
(40 \%)\end{array}$ & $\begin{array}{c}8 \\
(13.3 \%)\end{array}$ \\
\hline $\begin{array}{l}\text { Computer, Elecs., } \\
\text { and Software (CES) }\end{array}$ & $\begin{array}{c}32 \\
(40.5 \%)\end{array}$ & $\begin{array}{l}27 \text { out of } 32 \\
(84.4 \%)\end{array}$ & $\begin{array}{c}8 \text { out of } 32 \\
(25 \%)\end{array}$ & $\begin{array}{c}20 \\
(33.3 \%)\end{array}$ \\
\hline Medical & $\begin{array}{c}7 \\
(8.9 \%)\end{array}$ & $\begin{array}{l}5 \text { out of } 7 \\
(71.4 \%)\end{array}$ & $\begin{array}{c}2 \text { out of } 7 \\
(28.6 \%)\end{array}$ & $\begin{array}{c}5 \\
(8.3 \%)\end{array}$ \\
\hline Mechanical & $\begin{array}{c}20 \\
(25.3 \%)\end{array}$ & $\begin{array}{c}15 \text { out of } 20 \\
(75 \%)\end{array}$ & $\begin{array}{c}1 \text { out of } 20 \\
(5 \%)\end{array}$ & $\begin{array}{c}8 \\
(13.3 \%)\end{array}$ \\
\hline Other & $\begin{array}{c}10 \\
(12.7 \%)\end{array}$ & $\begin{array}{c}9 \text { out of } 10 \\
(90 \%)\end{array}$ & $\begin{array}{c}0 \text { out of } 10 \\
(0 \%)\end{array}$ & 0 \\
\hline
\end{tabular}

At one end of the spectrum, the CES cases form the largest group in the dataset at $40.5 \%$ ( 32 out of 79 cases), whereas at the other end, the pharmaceutical and semiconductor cases each constitute only $6.3 \%$ (5 out of 79 cases). The patents relating to mechanical and "other" cases appear the least likely to be relitigated. The one case out of 20 mechanical cases whose patent was subsequently litigated in 8 new cases appears to be an outlier, as mechanical patents tend to be litigated only once. $^{211}$ The figure below provides a graphical comparison of the relative percentages of the technology areas represented in the cases in the dataset with those of the new cases that were filed after the ruling on the vacatur motion:

211. See Allison et al., Extreme Value, supra note 207, at 18 ("Mechanical inventions make up only $8 \%$ of the most-litigated patents, but $53 \%$ of the once-litigated patents ...."). 
Figure 3: Technology Areas of Dataset Cases and New Cases Filed After Ruling on Vacatur Motion (Relative Percentages)

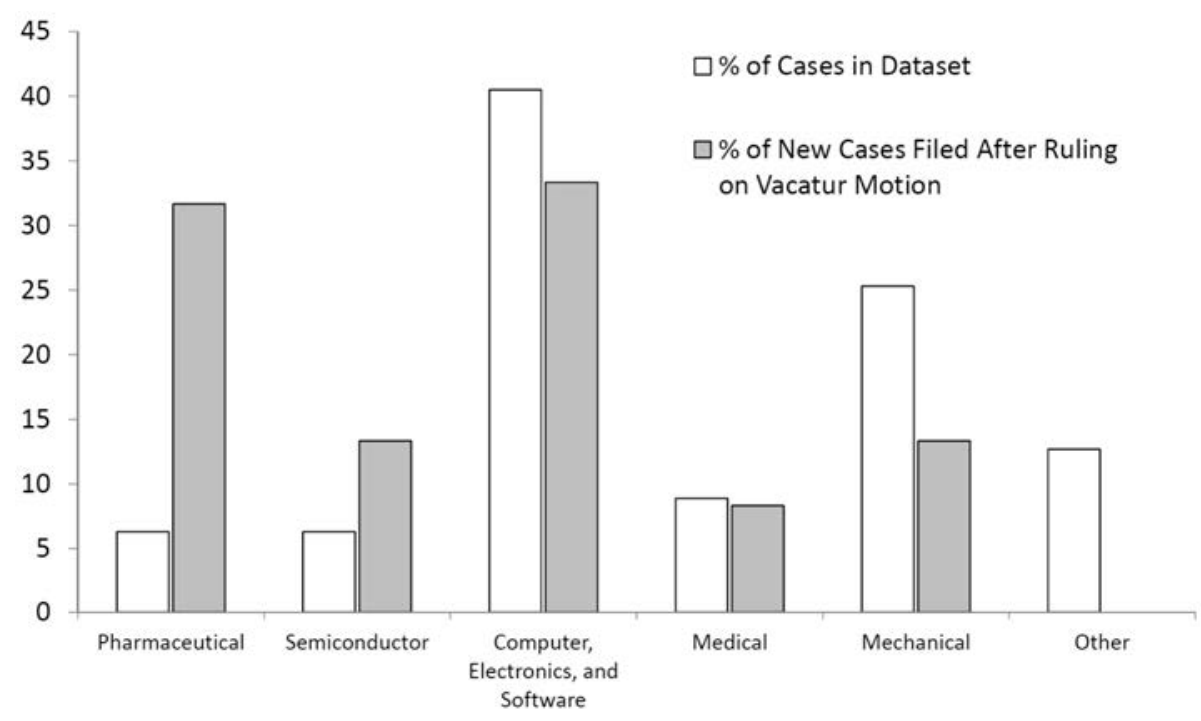

Although pharmaceutical cases were only $6.3 \%$ of the cases in the vacatur dataset, they constituted $31.7 \%$ (19 out of 60 ) of the new cases filed after the court ruled on the vacatur motion. Also notable is the number of new semiconductor cases filed out of proportion to their number in the dataset $(6.3 \%$ in the dataset; $13.3 \%$ of new cases) because semiconductor patents are not usually involved in repeat litigation. $^{212}$

The pharmaceutical cases and the CES cases together constitute the majority of the subsequent suits $(65 \%$; 39 out of 60 cases), which is consistent with prior research reporting that these two types of cases are disproportionately prone to repeat litigation. $^{213}$ This is unsurprising given the considerable size of the product markets associated with those technologies and the numerous potential accused infringers. This suggests that the preservation of potential collateral estoppel effect for the rulings in the pharmaceutical cases and the CES cases may have a greater beneficial impact on overall judicial economy and the public interest than in other types of cases where the likelihood of relitigation is low.

212. See Allison et al., Extreme Value, supra note 207, at 20 ("Notably absent from this list [of most-litigated patents] is the semiconductor industry . ..."); see also John R. Allison, Mark A. Lemley, Kimberly A. Moore \& R. Derek Trunkey, Valuable Patents, 92 Geo. L.J. 435, 474 (2004) ("While semiconductor patents constitute a substantial fraction of all patents issued, they are far less likely to be litigated than any other type of patent. Only $8.2 \%$ of the semiconductor patents in our sample study were litigated, compared with $24.3 \%$ of the nonsemiconductor patents." (footnotes omitted)).

213. Allison et al., Extreme Value, supra note 207, at 18-20. 


\section{Synthesis of Patent Characteristics and Likelihood of Relitigation}

In the preceding sections, the patentee types and technology areas represented in the vacatur dataset were evaluated separately. A matrix of the patentees and technologies may provide additional analytical granularity, as provided below for the 79 cases in the vacatur dataset (Table 14a), as well as the 60 subsequent cases that were filed after the ruling on the vacatur motion (Table 14b):

Table 14a: Patentee Types and Technology Areas in Dataset (\# of Cases; \% of 79)

\begin{tabular}{lccc}
\multicolumn{1}{c}{ Technology Area } & $\begin{array}{c}\text { Practicing } \\
\text { Company } \\
N=59\end{array}$ & $\begin{array}{c}\text { Patent Assertion } \\
\text { Entity (PAE) } \\
N=15\end{array}$ & $\begin{array}{c}\text { Individual } \\
N=5\end{array}$ \\
\hline \hline Pharmaceutical $(N=5)$ & $5(6.3 \%)$ & 0 & 0 \\
\hline Semiconductor $(N=5)$ & $4(5.1 \%)$ & $1(1.3 \%)$ & 0 \\
\hline $\begin{array}{l}\text { Computer, Elecs., and } \\
\text { Software }(\mathrm{CES})(N=32)\end{array}$ & $16(20.3 \%)$ & $13(16.5 \%)$ & $3(3.8 \%)$ \\
\hline Medical $(N=7)$ & $7(8.9 \%)$ & 0 & 0 \\
\hline Mechanical $(N=20)$ & $18(22.8 \%)$ & 0 & 0 \\
\hline Other $(N=10)$ & $9(11.4 \%)$ & $1(1.3 \%)$ & $0.5 \%)$ \\
\hline
\end{tabular}

Table 14b: Patentee Types and Technology Areas in Subsequent Cases (\# of Cases; \% of 60)

\begin{tabular}{lccc}
\multicolumn{1}{c}{ Technology Area } & $\begin{array}{c}\text { Practicing } \\
\text { Company } \\
N=41\end{array}$ & $\begin{array}{c}\text { Patent Assertion } \\
\text { Entity (PAE) } \\
N=19\end{array}$ & $\begin{array}{c}\text { Individual } \\
N=0\end{array}$ \\
\hline \hline Pharmaceutical $(N=19)$ & $19(31.7 \%)$ & 0 & 0 \\
\hline Semiconductor $(N=8)$ & $7(11.7 \%)$ & $1(1.7 \%)$ & 0 \\
\hline $\begin{array}{l}\text { Computer, Elecs., and } \\
\text { Software (CES) }(N=20)\end{array}$ & $2(3.3 \%)$ & $18(30 \%)$ & 0 \\
\hline Medical $(N=5)$ & $5(8.3 \%)$ & 0 & 0 \\
\hline Mechanical $(N=8)$ & $8(13.3 \%)$ & 0 & 0 \\
\hline Other $(N=0)$ & 0 & 0 & 0 \\
\hline
\end{tabular}


Comparing Tables $14 \mathrm{a}$ and $14 \mathrm{~b}$, it is notable that pharmaceutical cases brought by practicing companies and CES cases brought by PAEs together account for only $22.8 \%$ of the vacatur dataset but $61.7 \%$ of the subsequent suits. In addition, the number of CES cases in which vacatur motions were filed is similar for practicing companies and PAEs (16 versus 13, Table 14a), but the subsequent CES cases overwhelmingly involve PAEs ( 2 versus 18 , Table $14 \mathrm{~b}$ ). This difference is highly statistically significant. ${ }^{214}$ A comparison of the top five case types in Tables $14 \mathrm{a}$ and $14 \mathrm{~b}$ is provided below, with the differences bolded:

\section{Table 15: Top 5 Technology-Patentee Combinations}

\begin{tabular}{l|l}
\multicolumn{1}{c|}{ Vacatur Dataset (\% of 79) } & \multicolumn{1}{|c}{ Subsequent Cases (\% of 60) } \\
\hline \hline $\begin{array}{l}\text { 1. Mechanical / Practicing Co. (22.8\%) } \\
\text { 2. CES / Practicing Co. (20.3\%) }\end{array}$ & 1. Pharmaceutical / Practicing Co. (31.7\%) \\
3. CES / PAE (16.5\%) & 3. Mechanical / Practicing Co (13.3\%) \\
4. Other / Practicing Co. (11.4\%) & 4. Semiconductor / Practicing Co. (11.7\%) \\
5. Medical / Practicing Co. (8.9\%) & 5. Medical / Practicing Co. (8.3\%)
\end{tabular}

The data suggest that a patentee for whom litigation against potential infringers is critical to its business, such as PAEs and pharmaceutical companies, will likely reassert its patents after the ruling on the vacatur motion, even if it is denied. ${ }^{215}$ Where the factors point to a high likelihood of relitigation, denying vacatur to preserve collateral estoppel effect may ultimately yield greater benefits to judicial economy and the public interest than granting vacatur, not only because of the benefits of collateral estoppel and finality, but also because the most-litigated patents also tend to be the weakest, prevailing only $10.7 \%$ of the time if litigated to judgment. ${ }^{216}$ For example, patents asserted by PAEs, also known in the literature as "non-practicing entities" (NPEs), win only $9.2 \%$ of the time. ${ }^{217}$ Similarly, in

214. Using Fisher's exact test, the two-tailed p-value is 0.002 .

215. The 2 cases in the dataset whose patents were asserted in 4 new cases despite the denial of vacatur, see supra Table $11 \mathrm{~b}$, involved a PAE and a pharmaceutical company.

216. John R. Allison, Mark A. Lemley \& Joshua Walker, Patent Quality and Settlement Among Repeat Patent Litigants, 99 GEO. L.J. 677, 680 (2011) [hereinafter Allison et al., Repeat Litigants] ("[T]he most-litigated patents that go to judgment are far more likely to be held invalid or not infringed. ... Once-litigated patents win in court almost 50\% of the time, while the most-litigated — and putatively most valuable — patents win in court only $10.7 \%$ of the time.").

217. Id. at 680-81 ("NPEs [non-practicing entities] and software patentees overwhelmingly lose their cases, even with patents that they litigate again and again. Software patentees win only $12.9 \%$ of their cases, while NPEs win only $9.2 \%$."). 
pharmaceutical patent litigation, a study by the Federal Trade Commission found that patentees lost to generic companies $73 \%$ of the time between 1992 and $2000 .^{218}$

For some courts, the potential judicial economy arising from collateral estoppel may be more immediate and direct: $30 \%$ of the new cases (18 out of 60) were filed in the same district court where the prior (dataset) case was filed, and a clear majority of those new cases $(77.8 \%$; 14 out of 18$)$ that were filed in the same district was eventually assigned to the same judge who granted vacatur in the prior (dataset) case. One possible reason why a patentee may file subsequent suits in the same district is that the patentee believes that there is a high likelihood of being assigned to the same judge who is both familiar with the technology and has shown a willingness to grant settlement-related motions for vacatur. Indeed, as discussed previously, ${ }^{219}$ if a judge develops a reputation for reliably granting vacatur-which is becoming easier to establish unwittingly, given the advances in legal informatics that allow the systematic review of every docket item in every patent case for a specific judge-then patentees whose cases are assigned to that judge may attempt to adopt a "roll the dice" litigation strategy, where the prospect of guaranteed vacatur may lead them to take a wait-and-see approach that prolongs litigation in a weak case. For this reason, denying settlement-related vacatur, especially where the patentee is a repeat litigant, would be beneficial not only for long-term judicial economy and the public interest, but also for efficient near-term case management.

\section{F. Availability of Intervention}

As previously discussed, ${ }^{220}$ intervention is expected to be rare in the vacatur dataset. The results confirm this: motions to intervene were filed in only 4 out of the 79 cases in the dataset $(5.1 \%)$ for the purpose of opposing vacatur. ${ }^{221}$ In 3 of those 4 cases, the potential intervenor was adverse to the patentee in a parallel action involving at least one of the patents that would benefit from the grant of vacatur. Intervention was allowed in only one of the 4 cases, and in that one case, the court ultimately granted vacatur. ${ }^{222}$ The rarity of intervention motions is striking

218. Prepared Statement of the Federal Trade Commission Before the Special Committee on Aging of the United States Senate on Barriers to Generic Entry: Hearing Before the S. Spec. Comm. on Aging, 109th Cong. 10 (2006), available at http://www.ftc.gov/os/2006/07/P052103BarrierstoGenericEntryTestimonySenate07202006.p df ("The [Federal Trade] Commission studied all patent litigation initiated between 1992 and 2000 between brand-name drug manufacturers and Paragraph IV generic challengers, and found that the generics prevailed in cases involving 73 percent of the challenged drug products." (footnote omitted)).

219. See supra text accompanying note 177.

220. See supra notes 61-65 and accompanying text.

221. In the dataset, there were also 3 cases in which objections to the vacatur motion were lodged without an attempt to intervene: in 2 cases, the court provided an opportunity for the non-settling parties in related or consolidated cases to object, and, in the remaining case, a third party filed an objection without attempting to intervene.

222. The intervenor appealed the grant of vacatur, but voluntarily dismissed its appeal after settling with the patentee. Order, CollegeNET, Inc. v. XAP Corp., No. 3:03-cv-01229BR (D. Or. Oct. 1, 2009), ECF No. 934 (dismissal of appeal); Appellants ApplicationsOnline, LLC's and The Common Application, Inc.'s Statement of Issues for 
given that 43 out of the 79 cases $(54.4 \%)$ in the dataset involve patents with a history of litigation (prior or concurrent or both) that would benefit from the vacatur of certain adverse decisions. ${ }^{223}$ A patent with a history of litigation is likely to have third parties who would be concerned about its scope, validity, and enforcement issues in light of the patentee's litigiousness-yet, motions to intervene were filed in only 4 cases in the dataset.

Possible factors that may contribute to the scarcity of intervention motions may include timing and notice issues that make it difficult for third parties to timely file them. The table below summarizes the average and median number of days it takes a court to rule on a vacatur motion in the dataset, as measured between the date of the motion ${ }^{224}$ and the date of the ruling: ${ }^{225}$

\section{Table 16: Time Between Filing of Motion} and Ruling on Vacatur (in days)

\begin{tabular}{lccc} 
& $\begin{array}{c}\text { Cases }^{226} \text { with Ruling } \\
\text { on Vacatur Motion } \\
N=77\end{array}$ & $\begin{array}{c}\text { Vacatur } \\
\text { Granted } \\
N=62\end{array}$ & $\begin{array}{c}\text { Vacatur } \\
\text { Denied } \\
N=15\end{array}$ \\
\hline \hline $\begin{array}{l}\text { Range } \\
\text { (Low/High) }\end{array}$ & $0 / 333$ & $0 / 245$ & $1 / 333$ \\
Average & 25 & 19 & 48 \\
\hline Median & $\mathbf{4}$ & $\mathbf{4}$ & $\mathbf{1 1}$ \\
\hline Std. Dev. & 57 & 43 & 93
\end{tabular}

In the dataset, courts decided vacatur motions, on average, 25 days after they were filed. However, as shown in Table 16, this average appears to be heavily skewed by outliers. A more telling statistic is the median number of days. In approximately half of the cases where vacatur was granted (35 out of 62), the court issued its decision within 4 days. Notably, $22.6 \%$ of the decisions granting vacatur (14 out of 62) were issued at a pace that gave third parties less than a day to object prior to the court's decision: in 8 cases, the motion was granted the same day it was filed, and in 6 cases, the court granted vacatur without a formal written motion

Appeal at 2-3, CollegeNET, Inc. v. XAP Corp., No. 3:03-cv-01229-BR (D. Or. July 10, 2009), ECF No. 932 (issues appealed). As a result, an opportunity was lost for the Federal Circuit to directly consider the merits of a district court's decision to grant settlement-related vacatur.

223. See supra Part IV.E.1.

224. The date of the vacatur motion was calculated as described at supra note 137.

225. The date of the ruling used to calculate the elapsed time is the date the judge signed the ruling, not when the ruling was posted to PACER. Also, if the district court provided an indicative (or tentative) ruling and subsequently issued a formal order, the date coded was that of the formal order.

226. This does not include the 2 cases where the motion was withdrawn. 
having been filed beforehand, such that the first indication in the docket of the parties' intent to seek vacatur was the order granting it. ${ }^{227}$

The alacrity with which vacatur motions are typically granted may ultimately impair the ability of third parties to timely move to intervene prior to the court's ruling. Furthermore, because cases are often closed or dismissed the same day or shortly after vacatur is granted, it may be difficult for third parties to file a motion to intervene before the case has terminated, let alone before the grant of vacatur. ${ }^{228}$

Even if potential intervenors were to monitor the docket constantly, they may nevertheless be prevented from filing timely motions to intervene because of a failure of notice arising from vacatur motions that are not fully accessible to the public. In 9 out of 79 cases (11.4\%) in the dataset, the contents of the vacatur motion-or even its existence-were obscured from the public when the parties initially requested vacatur. In 3 of those cases, the earliest document that provided notice of the parties' intent to move for vacatur was filed under seal. ${ }^{229}$ In the remaining 6 cases, a written motion does not appear to have been filed, as indicated by the absence of any corresponding PACER docket entry, which suggests that those motions were raised during a hearing or a conference with the court, which are often held off-the-record if settlement is discussed. ${ }^{230}$ In such cases, a potential intervenor would not be aware of the existence of a request for vacatur until the court entered a ruling on the motion, at which point, it may be too late to intervene. The courts granted vacatur in 8 out of these 9 cases with notice issues.

Even in the absence of timing and notice issues, a timely motion for intervention is not likely to be granted. As previously noted, the preservation of collateral estoppel effect is not presently a basis for granting intervention as of right, and courts may be reluctant to grant permissive intervention when settlement is near. ${ }^{231}$ Indeed, 3 of the 4 intervention motions filed in the dataset were timely, yet intervention was granted in only a single case. The table below summarizes the conditions under which the intervention motions were filed and decided in those 4 cases, labeled A through D:

227. If no motion was filed, the time between the motion and the vacatur ruling was coded as zero days.

228. Intervention motions filed post-judgment or after dismissal—other than to request access to documents sealed under a protective order-are strongly disfavored. 6 MOORE, supra note 35 , at $\S \S 24.11,24.21$.

229. In coding whether a motion was filed under seal, the status of only the cover motion and any supporting memorandum of law was considered. The status of the declarations, exhibits, or other attachments was not considered, because those items are routinely filed under seal.

230. See, e.g., Perschbacher \& Bassett, supra note 2, at 25 ("[T]he meetings or conferences at which judges may encourage settlement tend to occur out of public view and off the record, thereby sheltering the judge's actions from scrutiny and eliminating the protections afforded in formal proceedings." (footnote omitted)); Resnik, Managerial Judges, supra note 6, at 402 n.115 ("Because most pretrial conferences are off the record, little documentation is available.").

231. See supra notes 63-65 and accompanying text. 
Table 17: Disposition of Intervention Motions Filed in Dataset (4 Total)

\begin{tabular}{|c|c|c|c|c|c|}
\hline Case & $\begin{array}{c}\text { Time Between } \\
\text { Vacatur } \\
\text { Motion and } \\
\text { Intervention } \\
\text { Motion } \\
\text { (in days) }\end{array}$ & $\begin{array}{c}\text { Intervention } \\
\text { Motion Filed } \\
\text { Before or } \\
\text { After Court } \\
\text { Ruled on } \\
\text { Vacatur } \\
\text { Motion? } \\
\end{array}$ & $\begin{array}{c}\text { Are Patentee } \\
\text { and Potential } \\
\text { Intervenor } \\
\text { Directly Adverse } \\
\text { re: Patents } \\
\text { Affected by } \\
\text { Vacatur? }\end{array}$ & $\begin{array}{l}\text { Intervention } \\
\text { Granted or } \\
\text { Denied? }\end{array}$ & $\begin{array}{l}\text { Vacatur } \\
\text { Ruling }\end{array}$ \\
\hline$A^{232}$ & 11 & After & $\begin{array}{l}\text { Yes (Adversarial } \\
\text { Negotiation and } \\
\text { Arbitration) }\end{array}$ & Denied & Granted \\
\hline $\mathrm{B}^{233}$ & 7 & Before & $\begin{array}{l}\text { Yes (Concurrent } \\
\text { Litigation) }\end{array}$ & $\begin{array}{l}\text { Denied, but } \\
\text { amicus } \\
\text { briefs } \\
\text { allowed }\end{array}$ & Denied \\
\hline$C^{234}$ & 1 & Before & $\begin{array}{l}\text { Yes (Concurrent } \\
\text { Litigation) }\end{array}$ & $\begin{array}{l}\text { Dismissed } \\
\text { as moot } \\
\text { after } \\
\text { vacatur } \\
\text { denial }\end{array}$ & Denied \\
\hline $\mathrm{D}^{235}$ & 7 & Before & $\begin{array}{l}\text { Yes (Concurrent } \\
\text { Litigation) }\end{array}$ & Granted & Granted \\
\hline
\end{tabular}

In short, the predominant manner in which district courts currently handle vacatur motions appears to introduce timing and notice issues that inhibit the timely filing of motions to intervene, which, when coupled with the courts' reluctance to grant permissive intervention when the parties are negotiating settlement, can create an environment where " $[\mathrm{t}]$ here will be no opposing voice when the parties move for vacatur," ${ }^{236}$ as noted by Judge Moore. To ameliorate this situation, district

232. Agere Sys. Inc. v. Atmel Corp., No. 2:02-cv-00864-LDD (E.D. Pa. June 30, 2006), ECF No. 435 (motion to intervene by Rohm Company, Ltd., filed under seal). That the patentee, Agere, and the potential intervenor, Rohm, were likely engaged in adversarial negotiations around the time of the intervention attempt, and were subsequently involved in arbitration, was revealed in a complaint that Agere later filed at the International Trade Commission to assert one of the patents that benefitted from the grant of vacatur. See Complaint at 35 II 106, Certain Semiconductor Integrated Circuits Using Tungsten Metallization \& Prods. Containing Same, Inv. No. 337-TA-648 (Apr. 18, 2008).

233. Infineon Techs. N. Am. Corp. v. Mosaid Techs. Inc., No. 5:02-cv-05772-JF (N.D. Cal. July 31, 2006), ECF No. 116 (motion to intervene by Micron Technology, Inc.).

234. Avid Identification Sys. v. Phillips Elecs. N. Am. Corp., No. 2:04-cv-00183-TJW (E.D. Tex. Dec. 23, 2008), ECF No. 462 (motion to intervene by Allflex USA, Inc.).

235. CollegeNET, Inc. v. XAP Corp., No. 3:03-cv-01229-BR (D. Or. May 1, 2009), ECF No. 917 (motion to intervene by ApplicationsOnline, LLC and The Common Application, Inc.).

236. Ohio Willow Wood Co. v. Thermo-Ply, Inc., 629 F.3d 1374, 1376 n.1 (Moore, J., 
courts could consider the following options, which have already been used in some cases in the dataset:

(1) To provide an adequate opportunity for third parties to weigh in on the potential impact of vacatur, the court could establish a briefing window during which third parties may move to intervene or, alternatively, file amicus briefs. ${ }^{237}$

(2) To avoid notice issues, the court could require the entire motion for vacatur and its supporting documents-including the settlement agreement - to be publicly filed without redactions. ${ }^{238}$ If the parties are using as a bargaining chip the potential preclusive effect of an otherwise non-defective ruling that was created through the expenditure of public funds, then the public should be allowed to review the terms of the settlement agreement that was negotiated with that bargaining chip. Prohibiting the filing of vacatur motions under seal may also have the salutary effect of discouraging parties from seeking such relief. ${ }^{239}$

To the extent that providing an adequate opportunity for notice and objection by third parties could discourage some settlements, it would affect primarily those cases where the parties are attempting to use settlement-related vacatur as a substitute for appeal, for which the equitable remedy of vacatur is inappropriate. ${ }^{240}$

concurring).

237. Examples from the dataset: Scheduling Order, CollegeNET, Inc. v. XAP Corp., No. 3:03-cv-01229-BR (D. Or. Apr. 10, 2009), ECF No. 913; and Civil Minutes, Infineon Techs. N. Am. Corp. v. Mosaid Techs., Inc., No. 5:02-cv-05772 (N.D. Cal. July 24, 2006), ECF No. 111.

238. Example from the dataset: Order, PBI Performance Prods., Inc. v. Norfab Corp., No. 2:05-cv-04836-HB (E.D. Pa. June 26, 2008), ECF No. 117 (order unsealing joint motion for vacatur). The joint motion for vacatur in this case included the settlement agreement as an attachment. Joint Motion for Vacatur of the August 29, 2007 Order Invalidating U.S. Patent No. 6,624,096 for Obviousness at 10, PBI Performance Prods., Inc. v. Norfab Corp., No. 2:05-cv-04836-HB (E.D. Pa. June 9, 2008), ECF No. 113-1.

239. In one case in the dataset, the parties withdrew their vacatur motion after the court ordered them to justify their motion as well as their request to seal. See Assented-To Motion to Withdraw Pending Motions, Skyline Software Sys., Inc. v. Keyhole Corp., No. 06-cv10980 (D. Mass. Feb. 11, 2008), ECF No. 95 (withdrawal of vacatur motion); Procedural Order, Skyline Software Sys., Inc. v. Keyhole Corp., No. 06-cv-10980 (D. Mass. Feb. 5, 2008), ECF No. 93 (order requesting justification to seal).

240. See U.S. Bancorp Mortg. Co. v. Bonner Mall P'ship, 513 U.S. 18, 25 (1994); see also 12 MoORE, supra note 35, at $\$ 60.48$ [1] ("In fact, the courts always require that there be 'extraordinary circumstances' justifying relief [under Rule 60(b)(6)]. To read the provisions otherwise would permit the discretion vested in a court by Rule 60(b) to be used to make unnecessary inroads into judgments that would otherwise be final, or to transform Rule 60(b) into a substitute for appeals." (citations omitted)). 


\section{IMPLICATIONS AND RECOMMENDATIONS}

\section{A. Persuasive Precedent is Not Enough}

The data suggest that granting settlement-related vacatur is a false economy. As discussed throughout Part IV, district courts appear to be prioritizing near-term case management by granting motions for settlement-related vacatur even when it could undermine overall judicial economy and adversely affect the interests of the public at large. For cases involving repeat litigants, the benefits that may accrue from denying vacatur and preserving the preclusive effect of a ruling outweigh the incremental additional work involved in continued litigation through appeal, especially since the most-litigated patents are often weak and have a higher-thanaverage loss rate if litigated to judgment. ${ }^{241}$

Some may question, however, whether settlement-related vacatur is truly a cause for concern in view of the fact that a vacated ruling typically remains accessible to the public, other litigants, and other courts via PACER and electronic databases (for example, Lexis and Westlaw), such that a vacated ruling that is stripped of any preclusive effect may still be used as persuasive precedent. There are several reasons why the availability of persuasive precedent does not obviate the need to curtail the practice of settlement-related vacatur.

First, the fact that a ruling has been vacated may embolden patentees to continue to assert patents that may be weak and, at the same time, potentially discourage accused infringers from challenging dubious claims of infringement in view of the prospect of having to litigate without the potential benefit of collateral estoppel against a patentee who also has an informational advantage by virtue of having tested his major theories in a prior case. As previously noted, $93.3 \%$ of the new cases (56 out of 60) filed after the ruling on the vacatur motion involved patents associated with cases where vacatur was granted. ${ }^{242}$ Because the denial of vacatur may discourage the reassertion of weak patents and marginal claims of infringement, vacatur should generally be denied, including those cases where the patentee makes it an express condition of settlement. ${ }^{243}$

Second, if a later court declines to accord collateral estoppel effect to a prior ruling, and treats it instead as persuasive precedent, that prior ruling may be given greater persuasive weight if it remained "intact" than if it were vacated. This is because the reason for vacatur is not always apparent. ${ }^{244}$ As the data show, vacatur is granted usually without any reasoned explanation, ${ }^{245}$ such that other courts may not be able to discern the degree to which the prior court was confident in its ruling. ${ }^{246}$ In some cases, it is possible that the court granted vacatur, in part,

241. See supra notes 216-218.

242. See supra Tables 11a and $11 \mathrm{~b}$.

243. See supra Part IV.D.

244. See, e.g., Fisch, supra note 2, at 630 ("Although a vacated decision may remain in the case reporters, its precedential value is extremely limited. . . A litigant citing a vacated decision cannot be sure that the court did not vacate based on second thoughts about the legitimacy of the legal rulings." (footnote omitted)).

245. See supra Part IV.B.

246. Professor Jill Fisch suggests that "[c]ourts could resolve this problem by stating 
because it had doubts about its ruling in light of the popular perception that the claim construction reversal rate is "too high.", 247 Alternatively, the court might have been extremely confident in its ruling but granted vacatur for the sole purpose of facilitating settlement. Accordingly, in the absence of any substantive explanation of the reasons for granting vacatur, later courts might accord a vacated ruling less persuasive weight than it might otherwise deserve.

Third, the vacated ruling may not always remain accessible for use as persuasive precedent. In particular, the parties might request-as a further condition of settlement - that the court also order the removal of the vacated rulings from Lexis and Westlaw, ${ }^{248}$ and also from the court's electronic docket so that those rulings are no longer available on PACER. ${ }^{249}$ That some courts have in recent years ${ }^{250}$ ordered the removal of electronic versions of vacated rulings raises concerns as to how far courts would be willing to go to fulfill the conditions of the parties' settlement agreements. In addition, if courts were to routinely accord substantial persuasive weight to vacated rulings, the next logical step in the evolution of the joint motion for vacatur could be the inclusion of a provision whereby the settlement is contingent on the court issuing an opinion actively disavowing and criticizing the vacated ruling, so as to substantially weaken any persuasive value that it may have. Motions for settlement-related vacatur are, accordingly, a cause for concern in view of their potential for manipulation of judicial proceedings and the public record.

More generally, settlement-related motions for vacatur have the "look and feel" of collusion and cartel-like behavior: ${ }^{251}$ the once-opposing parties jointly seek vacatur of an adverse ruling so as to resurrect a patent that may be asserted against

explicitly the grounds for vacatur whenever they grant a motion to vacate . . ." Fisch, supra note 2 , at 630 n.211.

247. E.g., Jeffrey A. Lefstin, Claim Construction, Appeal, and the Predictability of Interpretive Regimes, 61 U. MIAMI L. REV. 1033, 1037 (2007) (“[C]omputing claim construction reversal rates has been a popular sport: numerous studies have reported claim construction reversal rates from about $25 \%$ to $50 \%$. Based on these statistics, the notion that the reversal rate is 'too high' has become firmly ingrained in the minds of commentators, practitioners, and judges alike ...." (footnotes omitted)). In the dataset, the de novo review of claim construction rulings was mentioned in at least 5 vacatur motions and in one of the few orders where the court provided a reasoned analysis of its decision to grant vacatur.

248. See, e.g., Order, Klein v. Nat'l R.R. Passenger Corp., No. 2:04-cv-00955 (E.D. Pa. Aug. 6, 2009), ECF No. 225 (granting vacatur and ordering removal of rulings from Lexis and Westlaw). In Klein, a personal injury case filed against Amtrak, the confidential settlement included a provision that called for the vacatur of certain published opinions and their removal from Lexis and Westlaw. Shannon P. Duffy, After Settlement, Opinions Erased in Amtrak Case, Legal Intelligencer, Aug. 19, 2009, at 1 (“[A] spokeswoman for Westlaw, said [the judge's] request to remove the opinions would 'absolutely' be honored, and that any instance in which a judge vacates a published opinion automatically leads to its withdrawal from Westlaw's database. Calls to Lexis were not returned by press time.").

249. See, e.g., Docket Entry Text, SourceOne Global Partners, LLC v. KGK Synergize, Inc., No. 1:08-cv-07403 (N.D. Ill. Jan. 18, 2012), ECF No. 165 ("The agreed joint motion to vacate . . . is granted . . . [M] emorandum opinion and order (doc. \# 117) is hereby vacated; the Clerk of the Court is instructed to remove that memorandum opinion and order, and the accompanying minute order (doc. \# 116), from the docket.”).

250. See supra notes 248-249.

251. The author thanks Mark Lemley for this point. 
others in the industry. Although the grant of vacatur is a judicial act, the mere involvement of a court in connection with a settlement may not necessarily eliminate potential antitrust issues (a prime example being "reverse payment" agreements in pharmaceutical patent cases). ${ }^{252}$ Future research could investigate the antitrust implications of settlement-related vacatur in greater depth.

\section{B. Appellate Considerations}

Curtailing settlement-related vacatur may be difficult to accomplish without further guidance from the Federal Circuit that clarifies the standards for evaluating motions to vacate at the district court level. In particular, Bancorp should be formally extended to the district courts in a precedential Federal Circuit opinion. In addition to a clear pronouncement that "exceptional circumstances" do not include the mere fact that the parties have settled and are forgoing appeal, specific guidance on what does and does not constitute "exceptional circumstances" is needed in view of the data revealing that district courts are routinely vacating final judgments despite the "extraordinary circumstances" requirement of Rule 60(b)(6). ${ }^{253}$ To discourage gaming by the parties, the Bancorp standard should be further extended to interlocutory orders, rather than being limited to final judgments, since any impact on judicial economy arising from vacatur before or after the entry of judgment is largely one of degree. ${ }^{254}$ The formal extension of Bancorp to the district courts is long overdue and is a step that some district courts have already taken by applying the principles from Bancorp to deny vacatur of final decisions ${ }^{255}$ as well as interlocutory rulings. ${ }^{256}$

252. Cf. Mark L. Kovner, Colin R. Kass \& Avery W. Gardiner, Applying the Noerr Doctrine to Pharmaceutical Patent Litigation Settlements, 71 ANTITRUST L.J. 609, 629 n.54 (2003) ("[T]he fact that a settlement is 'so ordered' does not necessarily save it from antitrust liability.").

253. See supra Parts IV.A.2, B.

254. See, e.g., Allen-Bradley Co. v. Kollmorgen Corp., 199 F.R.D. 316, 318 (E.D. Wis. 2001) ("In terms of judicial economy, the difference between vacatur after judgment and vacatur before judgment, but after a Markman hearing and order, is only one of degree.").

255. See, e.g., Medtronic Vascular, Inc. v. Boston Sci. Corp., No. 2-06-cv-78, 2009 U.S. Dist. LEXIS 10109, at *7 (E.D. Tex. Feb. 11, 2009) ("“T]he parties have failed to show an equitable entitlement to an 'extraordinary remedy' of vacatur. The only reason presented... is that the parties have entered into a settlement agreement. Granting a vacatur... would effectively result in the exact same relief that Bancorp holds is inappropriate.”); Order, PBI Performance Prods. Inc. v. Norfab Corp., No. 2:05-cv-04836 (E.D. Pa. June 25, 2008), ECF No. 115, at 1 (citing Bancorp in denying vacatur).

256. See, e.g., Allen-Bradley, 199 F.R.D. at 320 ("[The] claim construction order, like nearly all court decisions and orders, affects interests beyond those of the parties in the present action. The benefits of settling the present action are, in short, outweighed by the systemic costs that would be incurred by vacating the court's order."); Zinus, Inc. v. Simmons Bedding Co., No C 07-3012 PVT, 2008 U.S. Dist. LEXIS 33359, at *6 (N.D. Cal. Apr. 23, 2008) (“[T] he court entertained several rounds of briefing, . . . heard an hour of oral argument, and spent several days drafting the [summary judgment] opinion. The public paid for this use of court resources through its tax dollars. Vacatur would render that expenditure a waste....”). 
Any doctrinal changes adopted by the Federal Circuit that are intended to restrict the practice of settlement-related vacatur may be more effective if the Federal Circuit's Mediation Guidelines were also updated to support that objective. If the Circuit Mediators are suggesting the filing of vacatur motions during mediation sessions, this could potentially send mixed messages to litigants and district courts as to whether settlement-related vacatur is somehow being condoned by the Federal Circuit. Although, as a matter of official court policy, the Federal Circuit and its Appellate Mediation Program take no position on whether such motions should be granted ${ }^{257}$ the very fact that a Circuit Mediator had suggested the vacatur motion could nevertheless make that motion appear more legitimate or compelling than may be warranted by the circumstances. For example, over a year after issuing the precedential order in Ohio Willow Wood, the Federal Circuit remanded a case $e^{258}$ to allow the parties to jointly move the district court to vacate an invalidity ruling. At the district court, third parties objected to the vacatur motion, ${ }^{259}$ and the patentee-a PAE—emphasized in its briefing that the Chief Circuit Mediator had suggested moving to vacate the invalidity ruling in order to facilitate settlement. ${ }^{260}$ The district court granted vacatur. ${ }^{261}$

Finally, the fact that the Federal Circuit has not yet had an opportunity to consider the merits of a district court's decision to grant vacatur is symptomatic of the high barrier to intervention by third-party objectors, as discussed previously. ${ }^{262}$ At the appellate level, this barrier is further heightened by the Federal Circuit whenever it adopts a rigid, narrow reading of the applicable regional circuit law in evaluating the timeliness of an intervention motion. ${ }^{263}$ Whether a motion to

257. See supra note 87 and accompanying text.

258. Ameranth, Inc. v. Menusoft Sys. Corp., 2012 U.S. App. LEXIS 849 (Fed. Cir. Jan. 13, 2012).

259. Motion for Leave to File Brief of Amicus Curiae Profitstreams, LLC, Ameranth, Inc. v. Menusoft Sys. Corp., No. 2:07-cv-271-DF (E.D. Tex. Nov. 4. 2011), ECF No. 333; Motion by Non-Party Seamless N. Am., LLC for Leave to File Amicus Curiae Brief, Ameranth, Inc. v. Menusoft Sys. Corp., No. 2:07-cv-271-DF (E.D. Tex. Nov. 11, 2011), ECF No. 334.

260. On remand in Ameranth, the patentee stressed the Chief Circuit Mediator's role in suggesting the vacatur motion that targeted the invalidity decision:

The public interest in resources expended by this Court and by the

Federal Circuit would be respected by vacatur of the invalidity verdicts and

judgment ... . The Federal Circuit's objectives would also be respected since the settlement would not have been reached without the efforts of the

Chief Federal Circuit Mediator and his suggestion of the motion for vacatur to facilitate the settlement.

Plaintiff Ameranth's Opposition to Non-Party Seamless N. Am., LLC's Motion for Leave to File Amicus Curiae Brief at 10-11, Ameranth, Inc. v. Menusoft Sys. Corp., No. 2:07-cv-271DF (E.D. Tex. Nov. 15, 2011), ECF No. 336 (emphasis added).

261. Order, Ameranth, Inc. v. Menusoft Sys. Corp., No. 2:07-cv-271 (E.D. Tex. Feb. 6, 2012), ECF No. 355 (granting vacatur).

262. See supra Part IV.F.

263. See, e.g., Ericsson, Inc. v. InterDigital Commc'ns, 418 F.3d 1217, 1222, 1224 (Fed. Cir. 2005) (reversing district court's grant of intervention because "[third-party objector's] motion to intervene failed to satisfy the Fifth Circuit requirement that there be an existing 
intervene is timely is not an inquiry that can be satisfied by bright-line rules. ${ }^{264}$ Accordingly, when evaluating the timeliness of an intervention motion filed to oppose the grant of settlement-related vacatur, the Federal Circuit should also consider the broader context of whether the public had adequate notice and an opportunity to timely intervene.

\section{CONCLUSION}

The grant of settlement-related motions for vacatur is presently the rule rather than the exception in patent cases at the district court level. Where the decision targeted for vacatur relates to the scope, validity, or enforceability of a patent, granting vacatur may be a false economy. This is especially the case when, as the data reveal, most courts are granting vacatur summarily ${ }^{265}$ without regard to the litigation history of the patent; ${ }^{266}$ the litigiousness of the patentee; $;{ }^{267}$ whether the targeted ruling is final or interlocutory, ${ }^{268}$ the existence of concurrent proceedings involving the same patent; ${ }^{269}$ or whether third parties have adequate notice and an opportunity to object. ${ }^{270}$ In addition, settlement-related vacatur does not appear to substantially change the timing of settlements ${ }^{271}$ or case duration ${ }^{272}$ at the district court level; rather, it appears to function primarily as a bargaining chip during settlement negotiations. ${ }^{27}$

The district courts' willingness to grant vacatur leaves the judiciary vulnerable to strategic behavior ${ }^{274}$ and manipulation ${ }^{275}$ by litigants-especially repeat players-and burdens the public with the anticompetitive effects of weak patents. ${ }^{276}$ For this reason, settlement-related vacatur of any rulings affecting patent liability issues should be denied in the absence of "exceptional circumstances.",277

suit in which to intervene" and, on that basis, deeming it unnecessary to reach merits of district court's vacatur ruling).

264. In general, courts evaluate the following four factors to determine timeliness:

(1) The length of time the intervenor knew or should have known of its interest in the case before moving to intervene;

(2) The prejudice to the original parties, if intervention is granted, resulting from the intervenor's delay in making its motion to intervene;

(3) Prejudice to the intervenor if the motion is denied; and

(4) Any unusual circumstances mitigating for or against a determination that the motion is timely.

6 MoORE, supra note 35, § 24.21 .

265. See supra Part IV.B.

266. See supra Part IV.E.1.

267. See supra Part IV.E.2.

268. See supra Part IV.A.2.

269. See supra Part IV.E.1.

270. See supra Part IV.F.

271. See supra note 129 and accompanying text.

272. See supra Table 7.

273. See supra note 173 and accompanying text.

274. See supra text accompanying note 219.

275. See supra notes $248-250$ and accompanying text.

276. See supra notes $215-218$ and accompanying text.

277. See supra text accompanying notes 253-256. 
In short, a patentee who miscalculates his chances of prevailing and fails to settle prior to the issuance of an adverse ruling should not be allowed to escape the consequences of that ruling at the public's expense. 


\section{APPENDIX A: IPLC SEARCH PARAMETERS}

To find the relevant cases, the following search parameters were used to gather an initial list of docket entries that were individually reviewed to identify each case in which a settlement-related vacatur motion was filed that satisfied the subject matter and time period restrictions of the vacatur dataset:

Search Keywords: vacat*

Case Type: patents

None of these words: reset reexamination "briefing schedule" "status conference" "markman hearing" "construction hearing" usca "case management conference" transfer "early neutral evaluation" "patentterm" "administrative order" unseal compel discovery "pro hac vice" limine default consolidating pretrial answer reply surreply response opposition "docket control order" "referring motion" "referring case to" "show cause" "scheduling conference" "initial disclosures" "protective order" "scheduling order" cmc rescheduled

Event Date Range: 01/01/2006 to 01/03/2011

If the relevance of a specific docket entry was not clear, the corresponding document was retrieved and reviewed. Documents not available on the IPLC were downloaded from PACER. The terms for the "None of these words" filter were chosen primarily to exclude the numerous items vacated in a typical case that relate to scheduling or administrative issues.

\section{APPENDIX B: WESTLAW SEARCH PARAMETERS}

In Westlaw, three databases were searched for case documents that might indicate that a settlement-related motion for vacatur was filed in the associated case: U.S. District Court Cases (DCT), Andrews Patent Litigation Reporter Court Documents (ANPATLR-DOC), and Federal Civil Trial Filings (FED-FILINGALL). The following search string was used:

\section{(VACAT! /P SETTLE!) \& (PATENT! NONINFRING! INVALID! "CLAIM CONSTRUCTION" MARKMAN) \& da(aft 12/31/2005 \& bef 1/4/2011) \% (HABEAS CONVICT! EMPLOYMENT EMPLOYEE! EMPLOYER! PRISON! "CLASS ACTION" "STATE LAW” ARREST! INSURANCE)}

For each document in the search result that appears to have been filed in a patent case in which a settlement-related motion for vacatur was filed, the associated docket was reviewed on the IPLC or PACER (or both) to determine whether the vacatur motion satisfied the subject matter and time restrictions of the vacatur database. 


\section{APPENDIX C: DOCKET NAVIGATOR SEARCH PARAMETERS}

In Docket Navigator, the following search parameters were used to find court orders that might indicate that a settlement-related motion for vacatur was filed in the associated case:

Search 1:

Type of Information: Court documents

Posture of Motion: Stipulated/Agreed OR Motion to Vacate

Document Text: vacat

Search 2:

Type of Information: Court documents

Type of Court Document: Motion to Vacate Prior Order

Search 3:

Type of Information: Court documents

Legal Issue: Vacating Judgment/Order

For each document in the search result that appears to have been filed in connection with a settlement-related motion for vacatur, the associated docket was reviewed in Docket Navigator or PACER (or both) to determine whether the vacatur motion satisfied the subject matter and time restrictions of the vacatur database. 